\title{
Re-evaluation of 'paradox of mesozooplankton' in the eastern Arabian Sea based on ship and satellite observations
}

\author{
R. Jyothibabu ${ }^{1}$, N. V. Madhu ${ }^{1}$, H. Habeebrehman ${ }^{1}$, K. V. Jayalakshmi $^{1}$, \\ K. K. C. Nair ${ }^{1}$ and C. T. Achuthankutty ${ }^{1}$ \\ ${ }^{1}$ National Institute of Oceanography, Regional Centre, Kochi - 682018, India
}

\begin{abstract}
In the central and eastern Arabian Sea (EAS), biomass and production of phytoplankton are known to vary spatially and seasonally whereas, biomass of mesozooplankton (MSP) is reported to be constant. This apparent contradiction has been called 'Arabian Sea Paradox'. However, it is important to note that the paradox of MSP is based on a very limited seasonal data (from 5-7 locations). Therefore, we reconsidered the paradox of MSP based on intensive in-situ observations at 39 - 40 locations in the EAS. In agreement with the known seasonal difference in phytoplankton standing stock in the EAS, we analysed the MSP data in two ways using two-way nested ANOVA. In 'basin scale' analysis, MSP data were analysed from the EAS were pooled and seasonal and inshore - offshore variations were analysed for the entire region. In 'regional scale' analysis, MSP data were analysed separately for (a) northern region (north of $15^{\circ} \mathrm{N}$ ) and (b) southern regions $\left(15^{\circ} \mathrm{N}\right.$ and south of it). Satellite data of chlorophyll $a$, SST and wind speed were also analysed to show the major differences in oceanographic features in the northern and southern EAS. The analyses showed prominently high chlorophyll a (av. $1 \mathrm{mg} \mathrm{m}^{-3}$ ) in the northern region during most of the year through winter convection, open ocean upwelling and lateral advection from the Arabian coast. On the other hand, chlorophyll a was low (av. $0.2 \mathrm{mg} \mathrm{m}^{-3}$ ) in the southern region during most of the year mainly due to thermohaline stratification. The MSP biomass was distributed almost in a similar way as that of phytoplankton stock with statistically significant spatial and seasonal variations in the northern and southern regions. In this paper, we review the 'paradox of MSP' and present clear and new evidences to show that this concept is not logically applicable for EAS.
\end{abstract}

Key words: - zooplankton, remote sensing, monsoon, upwelling, winter convection, chlorophyll $a$, eastern Arabian Sea

* Corresponding author, E-mail: rjyothi1@yahoo.co.in

Telephone - 91 (0) 484 2390814, Fax - 91 (0) 4842390618

An edited version of this paper was published by Elsevier. Copyright [2006] Elsevier 


\section{Introduction}

\subsection{An overview of the scientific background}

Mesozooplankton (MSP; $200-2000 \mu m$ ) plays a significant role in marine pelagic food web, and their ecological, trophodynamic and biogeochemical roles have been well recognised (Buitenhuis et al., 2006). The EAS, the western boundary of the Indian subcontinent, has several distinctive features in its plankton community compared to the rest of the Arabian Sea (Sarma, 2004). The first intensive effort that generated scientific knowledge on MSP community of the EAS was the International Indian Ocean Expedition (IIOE; 1960 - 1965). This programme with intensive observations in the EAS (Figure 1a) showed that MSP biomass varies seasonally and geographically. This feature is clearly seen in the plankton Atlas prepared subsequent to IIOE (Figure 1b \& c, Panikkar, 1968), with high biomass values along the southwest coast of India during the summer monsoon (April 16 to October 15) and along the northwest coast of India during the winter monsoon (October 16 to April 15). The open ocean regions of EAS had apparently low biomass during both the summer and winter monsoon periods (Panikkar, 1968; see the review by Madhupratap and Parulekar, 1993).

(Preferred position of Figure 1)

Subsequent to IIOE, several studies have confirmed the occurrence of high MSP biomass along the southwest coast of India during the summer monsoon period (May to September), and attributed this to the result of phytoplankton blooms caused by coastal upwelling (Johansen et al., 1978; Haridas et al., 1980; Raj and Ramamitram, 1981; Madhupratap et al., 1990; Ashadevi et al., 2009 - unpublished; Jyothibabu et al., 2008). However, a few earlier studies have observed that even in the absence of coastal upwelling, MSP biomass remains high along the southwest coast of India during the summer monsoon, due to land and river runoff (see the review by Madhupratap and Parulekar, 1993). Similarly, a few studies conducted in the northern Arabian Sea showed high MSP standing stock during the winter monsoon (November - February) and spring intermonsoon period (March - April), which was attributed to the winter blooms of phytoplankton (Haq et al., 1973; Paulinose and Aravindakshan, 1977).

Almost three decades after the IIOE, Madhupratap et al. (1992), based on observations along the shelf and slope regions of the southeastern Arabian Sea (SEAS), reported that MSP biomass remains unchanged during June - July (early summer monsoon) and November (early winter monsoon). They have observed low chlorophyll a during both monsoon periods; and opine that the observed 'high' MSP biomass during low chlorophyll a periods was a 'paradox'. Although the actual reasons for this 'high and unchanging' MSP biomass in low chlorophyll a regions had 
been obscure, they suggested the following plausible reasons for the observed disparity; (a) the high phytoplankton standing stock that would have existed a fortnight before the actual MSP measurement, (b) the high MSP grazing pressure during the sampling period that would have lead to low phytoplankton standing stock (top down control) and (c) the nutrition of MSP through a bacteria based food chain (microbial loop). However, none of these assumptions have been scientifically tested or proved so far. Moreover, a close observation of the data of this study reveals that the so-called 'high' MSP biomass was mostly restricted to the inshore regions, while the offshore regions had noticeably low values.

The Joint Global Ocean Flux Studies (JGOFS) was the most acclaimed oceanographic programme undertaken in the Arabian Sea during the recent past (1992-1997). The international scientific community, which participated in this programme, was mostly restricted to the central and western Arabian Sea. The Indian JGOFS measurements in the central and EAS (Figure 2) reported that the MSP biomass did not vary seasonally and geographically, even when a pronounced seasonal and geographical variation existed in the phytoplankton standing stock (Madhupratap et al., 1996a). This peculiar situation (maintenance of high MSP biomass during low phytoplankton conditions) was termed as the 'Arabian Sea Paradox'. However, it is quite evident from Figure 2, that this concept proposed was based on a limited number of observations without good seasonal coverage.

(Preferred position for Figure 2)

Subsequent to the IIOE, 'paradox of zooplankton' had also been referred from the western Arabian Sea (WAS). This was based on the observations made during the IIOE that MSP biomass remained high in the WAS during both winter and summer monsoon periods. The reason for the high MSP biomass during the summer monsoon was explained as a response to the intensive upwelling along the coast of Somalia and Arabia. However, the high MSP biomass observed during the winter monsoon period had been a mystery and this was referred to as a 'paradox' (Baars, 1999). Nonetheless, many recent studies including a reanalysis of IIOE data have proved beyond doubt that the high MSP biomass observed in the WAS during the winter monsoon was the result of winter convection and subsequent winter blooms. Thus, the 'zooplankton paradox' in the western Arabian Sea, which remained unexplained since the IIOE time, is now no more a paradox (Baars, 1994; Baars and Oosterhuis, 1998; Smith and Madhupratap, 2005).

Several inherent methodological differences can be seen between IIOE and recent studies, including Indian JGOFS, mainly with respect to the classification of seasons, selection of sampling depths and gear for MSP. During the IIOE, seasons were classified into two, summer monsoon (April 16 - October 15) and winter monsoon (October 16 - April 15) (Panikkar, 1968). The JGOFS classified a year into four seasons ie, summer monsoon (June - September), fall intermonsoon 
(October), winter monsoon (November - February) and spring intermonsoon (March - May). During IIOE, the Indian Ocean Standard Net (300 $\mu \mathrm{m}$ mesh size) was used for collecting MSP samples from the upper $200 \mathrm{~m}$ water column in a single haul, whereas in JGOFS, Multiple Plankton Net (200 $\mu \mathrm{m}$ mesh size) was employed for stratified vertical sampling of MSP. Therefore, it is rather difficult to make logical conclusions comparing the zooplankton data of IIOE and JGOFS.

Similar to the observations by Indian JGOFS in the central and EAS (Madhupratap et al., 1996), US JGOFS has also reported that MSP biomass remains unchanged in the central and WAS throughout the year (Wishner et al., 1998). However, several sediment trap measurements conducted in the WAS in recent decades (Nair et al., 1989; Haake et al., 1993; Rixen and Haake, 1993) showed marked increase in biogenic flux associated with the summer monsoon (June September) and winter monsoon (November to February). These results obviously point out the prevalence of low planktonic biomass in the upper water column of the WAS during the spring intermonsoon period (March - April). While almost entire phytoplankton production and more than $80 \%$ of the MSP production occur in the upper $200 \mathrm{~m}$, this is logically the layer from where maximum flux originates (Madhupratap and Parulekar, 1993). Some recent long term studies have also contradicted the observation of Wishner et al. (1998), by evidencing that the MSP standing stock is markedly lower in the WAS during the spring intermonsoon period compared to the monsoon periods (Luo et al., 2000; Koppelmann et al., 2003). These contradictions obviously represent the uncertainty that still prevails in the seasonal pattern of MSP distribution in the WAS.

\section{Materials and Methods}

\subsection{Study area \& environment}

The present study area, between latitudes $8-22^{\circ} \mathrm{N}$ and longitude $66-76^{\circ} \mathrm{E}$, comprises the Exclusive Economic Zone of India in the Arabian Sea. Figure 3 shows the study area and sampling locations. This region is very important to India economically, since more than $73 \%$ of its annual fish landing (2.2 to $2.8 \mathrm{mt} /$ year) originates from here (Madhupratap et al., 2001). The seasonally reversing monsoon winds (Figure 4a) play a major role on the plankton stock of this region thereby imparting a considerable influence on the fishery production. Major biologically productive natural systems in Indian waters such as mud banks, upwelling, river plumes, winter blooms etc. are strongly linked with the monsoon systems (Banse, 1959; Banse and McClain, 1986; Madhupratap and Parulekar, 1993; Madhupratap et al., 1996, 2001).

(Preferred position for Figure 3) 
The Arabian Sea is known for its thick oxygen minimum zone (OMZ; $\left.\mathrm{O}_{2}<5 \mu \mathrm{M}\right)$ in the intermediate depths (150 - $1200 \mathrm{~m}$ ), which increases northward from $10^{\circ} \mathrm{N}$ in the oceanic regions (Naqvi, 1987; Naqvi et al., 2006 and references therein). OMZ is an area found in the ocean where the circulation of water is poor and phytoplankton production in the surface waters is very high; causing high rate of organic matter sinking (consuming great amount of oxygen) in the intermediate water depths. The high biological productivity in the Arabian Sea is a known feature, which is strongly linked to the monsoon winds. The northward increase of the $\mathrm{OMZ}$ is well correlated with the highly productive overlying waters and is a combined effect of the high oxidation rates and oxygen depletion in the water available for renewal (Swallow, 1984; Madhupratap and Parulekar, 1993). Naqvi et al., (2006) showed that there are two suboxic zones in the EAS, one in the oceanic region north of $10^{\circ} \mathrm{N}$ and the other in the inshore region along the southwest coast of India. The main difference between the oceanic and coastal suboxic zones is that the former is perennial in nature, and the latter is highly seasonal occurring only during and shortly after the summer monsoon period (Naqvi et al., 2006).

During the summer monsoon period (May to September), intense south - westerly winds (Figure 4a) and eastward flowing summer monsoon currents (SMC) are characteristic of the SEAS (Figure 4b\&c) (Shankar et al., 2002). As summer monsoon progresses, surface waters of the inshore regions become nutrient enriched through coastal upwelling, land and river runoff. This eventually causes high biological production in the inshore regions during the summer monsoon period (Banse, 1959; Madhupratap et al., 1990; Nair et al., 1992; Bhattathiri et al., 1996). Although, summer monsoon season has traditionally been considered to be from June to September, recent observations clearly show that strong southwesterly winds and mature SMC occur in the eastern Arabian Sea from May to September (Shankar et al., 2002). Strong southwesterly winds during the period produce coastal upwelling and enhanced plankton standing stock and production along the southwest coast of India (Maheswaran et al., 2000, Maheswaran, 2004; Madhu, 2004). However, logically, there could be a time lag between the initiation of upwelling and its translation into biological production. Therefore, on a biological standpoint, we consider the summer monsoon from May 15 to September 30, winter monsoon from November 1 to February 28 and spring intermonsoon from March 1 to May 14 (Jyothibabu et al., 2008a).

(Preferred position for Figure 4)

During the summer monsoon, enrichment of coastal waters through river runoff appears to be an important factor influencing the biological production all along the west coast of India. The Indus, Narmada and Tapti are the major rivers among a dozen that empty into the north-eastern Arabian Sea. In the central and south west coast of India, a dense network of small rivers originating from the Western Ghats brings in freshwater. The estuarine regions of these rivers are 
rich and diverse in plankton community and with the onset of summer monsoon rain; most of these biological communities are flushed into the coastal waters (Achuthankutty et al., 1997; see review by Qasim, 2003, Jyothibabu, et al., 2006, Madhu et al., 2007).

As mentioned earlier, a proposed mechanism that may enhance biological production in the open waters of the Arabian Sea during the summer monsoon period is the upward Ekman pumping of nutrients along the Somalian and Arabian coast and its eastward advection towards the Indian coast (Figure 5; Prasannakumar et al., 2001). This process is reported to have considerable impact on the open waters of western and central Arabian Sea, but at present, we do not know about its extent of impact in the EAS. However, the pattern of chlorophyll a distribution evident in Figures 6 shows enhanced concentrations in the central and northeastern Arabian Sea (NEAS) during the peak and late summer monsoon period (July - September), possibly as a result of the mechanisms suggested by Prasannakumar et al. (2001), but certainly more studies would be required to confirm whether this process is important in the SEAS.

(Preferred position for Figure 5)

During the winter monsoon (November - February), the predominant cold north - easterly winds cause a cool, dry season with little rainfall, which is intense in the northern Arabian Sea. This cool dry climate combined with high ambient surface salinity $(>35)$ drives convective mixing, resulting in upward transport of nutrients from the top of the thermocline (Prasannakumar and Prasad, 1996; Madhupratap et al., 1996); which eventually translates into high biological production (Banse, 1968; Banse and McClain, 1986; Bhattathiri et al., 1996, Madhupratap et al., 1996b). Although typical climatic winter forcing in the northern Arabian Sea is pronounced during November - February, high concentration of entrained nutrients in the surface waters may persist further for several weeks (March). As a result, extensive phytoplankton blooms are common in the region till the end of March (Banse and McClain, 1986; Dwivedi et al., 2006; Prakash and Ramesh, 2007; Madhu et al., 2008). Dwivedi et al., (2006) noticed a lag of 2 to 3 weeks in the accumulation of phytoplankton biomass in response to wind forcing in the northern Arabian Sea during the winter monsoon. Normally, the freshwater influx is low along the west coast of India during the winter monsoon period (Rao and Rao, 1995). However there are instances when high rainfall was noticed along the southwest coast of India during the winter monsoon period (Madhupratap et al., 1992).

(Preferred position for Figure 5)

The spring intermonsoon (March - May 14) is a transition period between winter and summer monsoons. As a result of the weak winds and high solar radiation in the EAS, the mixed 
layer remains thin and more or less uniform (Prasannakumar and Prasad, 1996). In addition to this, the low saline, oligotrophic Bay of Bengal water, which occupies the surface layer of the SEAS intensifies stratification further during the spring intermonsoon period (Sanilkumar et al., 2003). This strong stratification results in depleted nutrients in the upper water column, more prominently in the SEAS (upper $60 \mathrm{~m}$ has near zero concentration of nitrate). This makes the region oligotrophic, characterised by the lowest annual phytoplankton standing stock and production (Bhattathiri et al., 1996). However, as mentioned earlier, the persistence of the impact of climatic winter forcing during March, makes the northern part of the EAS productive during the spring intermonsoon period.

It is well evident from the above account that the physical mechanisms that make the EAS biologically productive (upwelling and winter convection) are different in northern and southern regions during different seasons. The winter convection and enhanced phytoplankton production mostly occur north of $15^{\circ} \mathrm{N}$ during November to March; whereas coastal upwelling occurs south of $15^{\circ} \mathrm{N}$ during mid - May to September (Madhupratap et al, 2001). Overall message in the literature is that the SEAS remain oligotrophic during a major part of the year, but the NEAS has fairly high phytoplankton stock during most part of the year (Figure 6). Taking this into consideration, we have classified the EAS into two regions (a) northern (north of $15^{\circ} \mathrm{N}$ ) and (b) southern (south of $\left.15^{\circ} \mathrm{N}\right)$, for carrying out detailed analysis of plankton stock.

(Preferred position for Figure 6)

\subsection{The present approach}

In recent years, there has been an upsurge of scientific interest in using satellite chlorophyll a imageries to synoptically represent the oceanographic features (Banse and McClain, 1986; Chauhan et al., 2007; Smyth et al., 2001; Mizobata and Saitoh, 2004; Dwivedi et al., 2006; Prakash and Ramesh, 2007). In the present study, we have used SeaWiFS level - 3 images of chlorophyll a to represent primarily (a) the difference in the seasonal and geographical distribution of phytoplankton standing stock in the entire Arabian Sea basin and (b) the general relationship in the distribution of phytoplankton standing stock and MSP biomass in the EAS. Although level-3 images of SeaWiFS has an inherent problem of overestimating the chlorophyll a concentration in the near shore regions due to interference from sediment flux etc, it can still be efficiently used as a valuable tool for providing synoptic quantitative representation of the oceanic phytoplankton stock (www.http://disc.gsfc.nasa.gov/guides/GSFC/guide/SeaWiFS L3 Guide.gd.shtml).

In order to support our arguments on the seasonal distribution pattern of phytoplankton standing stock and MSP biomass, we have used the monthly SST data retrieved from MODIS (Moderate Resolution Imaging Spectroradiometer), wind speed from QuickSCAT and level - 3 
chlorophyll a data from SeaWiFS (SeaWiFS- USA) for the period from December 1999 - April 2004. These parameters were analysed separately for the northern and southern regions of the EAS. In order to reduce the chances in overestimation of chlorophyll a due to sediment flux in the near shore areas, in the present analysis, we omitted values from the inner shelf regions all along the Indian coast. We have also improved the quality of the chlorophyll a data by omitting values higher than $5 \mathrm{mg} \mathrm{m}^{-3}$ (Prakash and Ramesh, 2007), This practice is expected to reduce the error factor since the chances of overestimations are higher, when chlorophyll a values are high. In order to represent the chlorophyll a distribution pattern during the corresponding periods of MSP sampling, we have processed the ocean colour data of SeaWiFS.

\subsection{MSP}

Seasonal samples of MSP were collected from the EAS from 7 latitudinal transects $(8,10$, 13, 15, 17, 19 and $21.5^{\circ} \mathrm{N}$ ) onboard FORV Sagar Sampada. Altogether, 37, 39 and 40 stations were sampled during the winter, spring and summer monsoon periods (Figure 3 ). The sampling locations were categorised into (a) inshore (depth <200m) and (b) offshore (depth $>200 \mathrm{~m}$ ). One cruise each was carried out to represent the winter monsoon ( $1^{\text {st }}$ December 1999 to $5^{\text {th }}$ January $2000)$ and spring intermonsoon period $\left(15^{\text {th }}\right.$ April to $8^{\text {th }}$ May 2004). During the summer monsoon period, the rough sea conditions create practical difficulties to conduct intensive MSP sampling in the Arabian Sea. In fact, this difficulty has restricted the Indian JGOFS to sampling only one location in the open ocean, during the summer monsoon period (Figure 2). We have attempted a cruise in June 2001 (June $6^{\text {th }}$ onwards), but due to harsh weather, we could only cover stations along $8^{\circ} \mathrm{N}$ transect. In 2002 , we conducted a cruise from $20^{\text {th }}$ May to June $6^{\text {th }}$ (starting from $22.5^{\circ} \mathrm{N}$ transect southward) to cover the rest of the locations to represent the summer monsoon period. Thus the data collected in two successive summer monsoon cruises (in 2001 and 2002) were used to represent the entire EAS. The difficulty in stratified MSP sampling in the Arabian Sea during summer monsoon has been well documented during several international oceanographic programmes (Please see http://www.usglobec.org/reports/www.as/as.zooecology.html\#as.zp.5).

MSP samples were collected using a Multiple Plankton Net (Hydro - Bios, Germany). The Multiple Plankton Net was operated vertically to collect stratified samples up to a depth of $1000 \mathrm{~m}$. However, the data of the upper two layers (mixed layer and thermocline layer) were only considered for the present analysis, since it is well established that more than $90 \%$ of the MSP biomass in the Arabian Sea occurs with in the mixed and thermocline layers (Madhupratap et al., 1996a; Padmavati et al., 1998; Smith and Madhupratap, 2005). MSP samples collected during the daytime alone were considered for the present study so as to minimize the possible error in estimations due to upward migration of MSP with respect to the diminishing solar radiation. Immediately after the retrieval of the net, the MSP samples were filtered through a $200 \mu \mathrm{m}$ nylon sieve and excess water in the samples was removed using blotting paper. The biomass of the 
samples was measured following displacement volume method (Postel et al., 2000) and converted to dry weight using available numerical factors $(1 \mathrm{ml}$ displacement volume $=0.075 \mathrm{~g}$ dry weight; Madhupratap and Haridas,1986, 1990; Gauns et al., 2005).

The MSP biomass data from the mixed and thermocline layers were plotted in SURFER 8 (Golden Software, USA.) The MSP data were also pooled to analyse variations in (a) the entire EAS (basin scale) and (b) the northeastern and southeastern regions (regional scale). The basin scale approach was similar to the method followed by Madhupratap et al. (1996a) where data from the entire EAS during different seasons were pooled and compared. The inshore and offshore MSP data were pooled and compared within a season and between seasons to see whether there is any prominent inshore - offshore variability. In regional scale approach, the EAS was considered into two distinct regions (a) northern region (north of $15^{\circ} \mathrm{N}$ ) and (b) southern region $\left(15^{\circ} \mathrm{N}\right.$ and south of it) and the seasonal and inshore-offshore variations within northern and southern regions were compared.

\subsection{Two - way nested analysis of variance}

Nested ANOVA is an important tool to analyse the significance of variance of unequal sample sizes (Sokal and Rohlf, 1981). These designs are most useful when we have a random effects situation. When the sample sizes in a nested ANOVA are unequal, the P-values corresponding to the F-statistics may not be the exact estimates of the actual probability. However, we may get a better estimate of the exact P-value by using modified mean squares at each level, found using a correction formula called the Satterthwaites approximation. In situations when the Satterthwaite approximation test (Gaylor and Hopper, 1969) cannot be applied, in such cases the $\mathrm{P}$-values would be the result of a conservative approximation test. One important aspect of the two - way nested ANOVA is that it takes into consideration the two way classification of the whole data.

The equation of two way nested ANOVA $Y_{i j k}=A_{i}+B_{i j}+E_{i j k}$

Where $Y_{i j k}$ is the $k^{\text {th }}$ observation in the $j^{\text {th }}$ subgroup of the $i^{\text {th }}$ main group.

$A_{i}$ is the random contribution for the $i^{\text {th }}$ group of level $A$

$B_{i j}$ is the random contribution for the $j^{\text {th }}$ subgroup (level $B$ ) of the $i^{\text {th }}$ main group

$E_{i j k}$ is the error term of the $k^{\text {th }}$ item in the $j^{\text {th }}$ subgroup of the $i^{\text {th }}$ group.

The results of a two way nested ANOVA can be represented as;

$F^{\prime} G\left(f_{11}, f\right)=$ Calculated $F$ statistic value for main groups, $f_{1}$ and ${ }_{f 2}$ are first and second degree of freedom. 
In the present study, either sampling layers (mixed and thermocline) or geographical regions (inshore offshore or north - south) are taken as groups.

F SG $(f 1, f 2)=$ Calculated F statistic between subgroups. In the present study, seasons are taken as subgroups in all treatments.

\section{Results and discussion}

\subsection{Pattern of chlorophyll a with respect to SST and wind speed}

The general pattern of chlorophyll a distribution in the EAS is shown in Figure 6, which is in support of the already known seasonal pattern acquired by ship measurements (Bhattathiri et al., 1996; Madhupratap et al., 2001, Prasannakumar et al., 2001; Madhu, 2004; Dwivedi et al., 2006; Jyothibabu et al., 2008a). Enhancement of chlorophyll $a$ in the inshore regions of southern region during the peak and late summer monsoon period; and in the entire northern region during the winter monsoon period was evident in Figure 6. Apart from this, continued occurrence of high chlorophyll stock in the northern region during the early spring intermonsoon (Dwivedi et al., 2006) and in the central and northern parts of the EAS during the peak summer monsoon (Prasannakumar et al., 2001; Madhupratap et al., 2001) are the other two striking features in Figure 8. The high phytoplankton biomass in open waters of Arabian Sea, south of Findlater jet, is reported to be due to the eastward advection of upwelled nutrients from the Arabian coast (Figure 5 - Prasannakumar et al., 2001). In the SeaWiFS images this feature is very prominent during the peak/late summer monsoon period (July - September). It is also significant to see that even during the peak summer monsoon period, the magnitude of chlorophyll $a$ in the oceanic waters between 8 $-12^{\circ} \mathrm{N}$ transect is markedly low. Over all, when we look at the phytoplankton stock in the northern and southern regions of the EAS on an annual scale, it is obvious that the former region has high phytoplankton standing stock during 9 out of 12 months and the latter remains oligotrophic during 7 out of 12 months.

(Preferred position for Figure 7)

Monthly difference in the amount of chlorophyll $a$ in the northern and southern regions of the EAS from December 1999 to April 2004 is presented in Figure 7. This strongly supports our argument that on an annual scale phytoplankton stock in the SEAS is much lower compared to the NEAS. The only exception to this is the summer monsoon period when chlorophyll a concentration remains relatively high in the SEAS. However, it is important to note here that, there is a possibility of underestimating the coastal upwelling production of the SEAS in the present analysis, since we have omitted chlorophyll a values from the inner shelf regions. However, when considering the vastness of the study area, the error that might have occurred on the mean chlorophyll a value seems to be minor. 
The maintenance of high chlorophyll a concentration in the NEAS during the period from November to March is well evident in Figure 7, which truly corresponds to the atmospheric cooling and the subsequent winter blooms during these periods (Banse and McClain, 1986). The wellknown atmospheric cooling in the NEAS during November to March period (with $\sim 5^{\circ} \mathrm{C}$ mean drop compared to the summer) is obvious in the monthly SST presented in Figure 8 . It is also evident in this figure that the magnitude of surface cooling in the SEAS during November to March is minor $\left(\sim 1.5^{\circ} \mathrm{C}\right.$ mean drop compared to summer), pointing towards the lack of winter convection and subsequent enhancement of phytoplankton stock (Figure $7 \& 8$ ). Fairly high phytoplankton biomass was also seen in the NEAS during the peak/late summer monsoon period (Figures 7). As mentioned earlier, this high value might have been mainly contributed by the mechanism of open ocean upwelling and lateral advection as suggested by Prasannakumar et al. (2001).

\section{(Preferred position for Figure 8)}

QuickSCAT wind data presented in Figures 9 clearly shows increased velocity during the summer monsoon $\left(8 \pm 2 \mathrm{~m} \mathrm{~S}^{-1}\right)$ compared to winter monsoon $\left(5 \pm 2 \mathrm{~m} \mathrm{~S}^{-1}\right)$ and spring intermonsoon periods $\left(4 \pm 2 \mathrm{~m} \mathrm{~S}^{-1}\right)$. Although there are differences of opinion on the mechanism responsible for the initiation of upwelling along the southwest coast of India, the pivotal role of strong south westerly winds has been well established (Shetye et al., 1985; Muraleedharan and Prasannakumar, 1996; Smitha et al., 2007). Now, it is fairly understood that the strong southwesterly winds, during the summer monsoon period deepens the mixed layer in the offshore region and results in coastal upwelling along the shelf regions of the SEAS (Jyothibabu et al., 2008a and references therein). It is important to note that the mean phytoplankton stock in the SEAS remains relatively high only during the summer monsoon period (Figures 7 ).

The winds are weaker in the SEAS during the winter (av. $5 \pm 2 \mathrm{~m} \mathrm{~S}^{-1}$ ) and spring intermonsoon (av. $4 \pm 1 \mathrm{~m} \mathrm{~S}^{-1}$ ) periods compared to the summer monsoon (av. $8 \pm 2 \mathrm{~m} \mathrm{~S}^{-1}$ - Figures 9). This weak wind seems to be inefficient to erode the surface layer stratification in the SEAS during the winter and spring intermonsoon periods; caused by the warm $\left(>28^{\circ} \mathrm{C}\right)$ and low saline $(<34 \mathrm{psu}$ ) Bay of Bengal water. Similar to the SEAS, winds were also weak in the NEAS during the winter monsoon (av. $5.5 \pm 2 \mathrm{~m} \mathrm{~S}^{-1}$ ) but cooler than the former region. The surface salinity in the NEAS is 2-3 higher than that of the SEAS (Prasannakumar and Prasad, 1996). Thus, the combined effect of the high salinity, cool and dry winds cause convective mixing and entrainment of nutrients, which ultimately trigger winter booms from November to March.

(Preferred position for Figure 9) 
The inshore region of the NEAS is also reported to have high phytoplankton standing stock during the summer monsoon period, but the actual mechanisms responsible for this is poorly known even though river and land runoff are suggested as possible reasons (Madhupratap and Parulekar, 1993; Madhupratap et al., 2001). The SeaWiFS images presented in Figure 6 also show high chlorophyll concentration in the inshore regions of the NEAS during the summer monsoon period. However, there is a strong possibility of overestimation of chlorophyll a in these regions since a considerable amount of sediment flux originating from Indus, Narmada and Tapti Rivers get dispersed in this region during the summer monsoon period, (Rao and Rao, 1995). Also the strong tidal currents prevailing in the Gulf of Khambat (maximum tidal range $11 \mathrm{~m}$ ) and Gulf of Kachchh $(7 \mathrm{~m})$ can cause re-suspension of sediments in the respective regions (Ramaswamy et al., 2007), leading to overestimation in the SeaWiFS level - 3 images.

SeaWiFS chlorophyll a images corresponding to MSP sampling periods are shown in Figure 10. Although chlorophyll a concentration of a major portion of the study area is not represented in the images during June 2001, and May- June 2002 due to cloud cover, the seasonal trend in distribution was similar to that discussed with respect to Figures $6 \& 7$. However, the enhancement of chlorophyll $a$ in the open ocean region through lateral advection as suggested by Prasannakumar et al. (2001), was not very prominent during May - June 2002. Further, the area south of $12^{\circ} \mathrm{N}$ was not at all influenced by the laterally advected nutrients from the WAS. This could be due to two reasons: (a) the waning of the laterally advected nutrients from the western Arabian Sea before reaching the EAS and (b) the present sampling was during the early southwest monsoon and therefore the impact of laterally advected nutrients were not prominent. On the other hand, during the winter and spring intermonsoon periods, elevated concentrations of chlorophyll a were present in the northern Arabian Sea due to winter convection and its persistence during the spring intermonsoon (Madhupratap et al., 1996; Dwivedi et al., 2006). It is well evident in Figure 6\&7 that the SEAS remain less productive, during the winter and spring intermonsoon due to the persistence of low saline Bay of Bengal water (Jyothibabu et al., 2008a). The results of recent ship based chlorophyll a measurements (Table 1) support our argument that phytoplankton stock in the EAS show strong seasonal pattern.

(Preferred position for Figure 10)

\subsection{MSP}

\subsubsection{General distribution in relation to chlorophyll a}

The seasonal and geographical distribution of MSP biomass in the mixed and thermocline layer is shown in Figure 11. Before proceeding further, it is important to analyse here, the 
postulated ambiguity in relating the phytoplankton and zooplankton biomass. Several studies showed that the nutrient enrichment, phytoplankton and MSP biomass accumulations are not directly coupled even though a linear relationship is proposed theoretically (Madhupratap and Parulekar, 1993 and references therein). This disparity is primarily assigned to (a) the time lag in conversion of phytoplankton biomass to the MSP biomass (b) the differential grazing activity of higher organisms such as fishes on phytoplankton and MSP and (c) the interaction of alternate nutritional pathways such as microbial loop or detritivorous food web (Sladeck, 1958; Madhupratap and Parulekar, 1993). However, in some instances the postulated time lag between nutrient enrichment, development of phytoplankton, succession of herbivores and carnivores were not observed (Madhupratap and Haridas, 1986). Due to these complexities in directly relating the MSP biomass with phytoplankton standing stock, in the following section, we analysed the general variation in magnitude of MSP biomass in the northern and southern regions of the EAS, with the observed seasonal trend in the phytoplankton standing stock.

\subsubsection{Summer monsoon}

The most prominent feature observed (Figures 11 a \& b), was the markedly high MSP biomass in the mixed and thermocline layers along the southwest coast of India. An increase in biomass, however was generally noticeable along the west coast of India, extending up to $17^{\circ} \mathrm{N}$, with exceptionally high values between 8 and $10^{\circ} \mathrm{N}$ (Figures $11 \mathrm{a} \& \mathrm{~b}$ ). Nonetheless, the expected high MSP biomass in the offshore region of the central and NEAS, due to open ocean upwelling was not discernible in the present data. Similarly, a high MSP biomass in the inshore waters of the northern region due to land and river runoff was also not reflected in the present data.

One possible reason for not reflecting the expected enhancement in MSP biomass in the central and NEAS could be due to the timing of the present sampling which was during the onset of summer monsoon (May $20^{\text {th }}$ to June $6^{\text {th }}$ ). Although monsoon winds and coastal upwelling are active from May, the prominent phytoplankton accumulation in the offshore region of the central and NEAS occurs during the peak/late summer monsoon period (July - September). Therefore a corresponding MSP biomass accumulation in these regions can only be expected during peak/late summer monsoon period. Contrary to this, the data collected during the peak summer monsoon (August - September 2004) from the SEAS (Ashadevi et al., 2009) also showed a trend similar to that of the present study, with exceptionally high MSP biomass in the inshore regions and markedly low concentrations in the offshore region. These observations point to the fact that the influence of the laterally advected nutrients from the Somalian upwelling was probably not very effective in enhancing the MSP standing stock in the offshore waters of the SEAS.

The enhancement of MSP biomass in the upwelling areas along the Indian coast has been well documented. The possible reasons suggested for this biological feature are: 
(a) The phytoplankton community inhabiting in the inshore regions are efficient in utilizing the newly available nutrients. Due to the high supply of nutrients and optimum solar radiation in the coastal upwelling regions, the growth rate of phytoplankton would be high, which may support high MSP biomass. This possibility seems to be relevant, since some earlier studies have shown that MSP grazing and vertical biomass accumulations are positively related to the phytoplankton growth rate (Kiorbe, 1989; Herman, 1983). Dilution experiments by Landry et al. (1998) in the WAS also supported the above contention, in that phytoplankton community growth rate (division rate 0.9 to $2.2 \mathrm{~d}^{-1}$ ) in the coastal upwelling areas was much higher compared to the oligotrophic offshore regions (division rate $<0.5 \mathrm{~d}^{-1}$ ). Similarly, the phytoplankton growth rate in the inshore regions during upwelling (division rate 0.9 to $2.2 \mathrm{~d}^{-1}$ ) was evidently higher than that of the winter monsoon period (division rate 0.3 to $1.3 \mathrm{~d}^{-1}$ ). Unfortunately, such measurements are lacking from the Indian coastal waters. Alternatively, instead of considering the high growth rate of the entire phytoplankton community in the upwelling regions, Banse et al, (1996) have suggested that it may be the high growth rate of large diatom that would maintain high MSP biomass. This is particularly significant, because most of the MSP groups feed on microplankton, as nano and picoplankton are small size for them to consume. It has been suggested by Poulet and Marsot (1978) that herbivorous copepods perceive diatom cells by chemosensory means, and elevated phytoplankton growth rate results in a larger phagostimulating effect around individual algal cells, that enhances copepod-grazing rate (Cowles et al., 1988).

(b) The availability of abundant organic detritus and microzooplankton (also related to river runoff) as direct food source for MSP is another factor that may positively influence the MSP biomass along the southwest coast of India (See review by the role of organic detritus by PechenFinenko, 1987 and references therein). Several species of copepods inhabiting in the coastal areas actively consume organic detritus as a supplementary nutritional source. Similarly, a model by Parson and Kessler (1986) shows that the initial presence of microzooplankton in fresh water plumes might increase secondary production by several orders of magnitude. The abundance of microzooplankton in Cochin backwaters is phenomenal (>10000 ind.litre $\left.{ }^{-1}\right)$ during pre-summer monsoon (March - April) period, and this high standing stock is more or less completely flushed into the coastal regions during the onset of monsoon rains (Jyothibabu et al., 2006). The same could also be true in other estuaries along the southwest coast of India during the southwest monsoon season. There are also evidences to suggest that microzooplankton is more preferred by several MSP species in the estuarine and coastal waters due to its high nutritional content (Stoecker and Egloff, 1987; Stoecker and Capuzzo, 1990).

\subsubsection{Winter monsoon}

The geographical difference in distribution of MSP biomass was also evident during the winter monsoon period (Figures $11 \mathrm{c} \& \mathrm{~d}$ ). More or less similar pattern was found in both mixed 
and thermocline layers with high biomass in major part of the NEAS. Relatively, low biomass was found in the southern region, with a few pockets of high biomass in the inshore waters. These high biomass pockets have resulted due to the patchiness of MSP, which is common in the Arabian Sea (Mathew et al., 1990; Kidwai and Amjad, 2000). The enhancement in MSP biomass in the northern region during the winter monsoon was obviously an outcome of high phytoplankton standing stock through convective mixing. A close observation of the MSP distribution in the northern region indicates high concentration in the Gulf of Kambat and neighbouring waters. This could primarily be the result of exceptionally high phytoplankton stock in this region during winter monsoon period as is evident in the processed IRS P4 images (Dwivedi et al., 2004; Chauhan et al., 2007).

In the southern region, persistence of high MSP biomass was observed in the inshore regions compared to the offshore region (Figure $11 \mathrm{c} \& \mathrm{~d}$ ); a feature noticed since the IIOE measurements (Panikkar, 1968; Madhupratap et al., 1992). A possible reason for this high MSP biomass along the coastal regions of the SEAS could be the freshwater influx. Although the major part of the annual rain along the southwest coast of India occurs during the summer monsoon period, a moderate amount of rainfall $(\sim 30 \%)$ also occurs during the winter monsoon period (Madhupratap et al., 1992; Qasim, 2003). Three estuarine systems viz. Ashtamudi ( $8^{\circ} 53^{\prime} \mathrm{N}-09^{\circ}$ $\left.02^{\prime} \mathrm{N}\right)$, Cochin backwaters $\left(9^{\circ} 30^{\prime} \mathrm{N}-10^{\circ} 10^{\prime} \mathrm{N}\right)$ and Netravati - Gurupur $\left(12^{\circ} 48^{\prime} \mathrm{N}-12^{\circ} 53^{\prime} \mathrm{N}\right)$; empty into the inshore regions of the SEAS, probably contributing to the increase in MSP biomass during the winter monsoon period also. Another possible reason for the high MSP biomass could be the Bay of Bengal water, which occupies the SEAS during the winter monsoon period. The coastal waters of southwestern Bay of Bengal is fairly productive during the winter monsoon due to heavy rain fall over the catchment areas of the major eastward flowing Indian rivers such as Krishna, Kaveri and Godavari. As a result, the MSP standing stock in the inshore regions of the southwestern Bay of Bengal shoots up during the winter monsoon and remains highest of all the seasons (Jyothibabu et al., 2008 b).

\section{Preferred position of Figure 11}

Prasannakumar et al., (2004) has reported the intrusion of Bay of Bengal water into the EAS during the winter monsoon and enhancement of chlorophyll $a$ in the inshore waters. However, transport of MSP community from the western Bay of Bengal to the inshore regions of SEAS along with winter monsoon current has not yet been addressed. A recent study off Kalpakkam (in the southernmost part of the Indian east coast) has reported major changes in the phytoplankton and MSP communities with respect to the change in the direction of coastal currents (Saravanane et al., 2000). This is the first direct evidence for the possible seasonal transport of MSP community between southeastern Arabian Sea and southwestern Bay of Bengal. The importance of coastal 
currents in transporting copepods between geographically distant regions has been fairly known from elsewhere (see Hwang and Wong, 2005 and references therein).

It is important to note that the magnitude of MSP biomass in the NEAS during winter is relatively less, compared to the summer monsoon production along the southwest coast of India. This feature has been brought out earlier in the MSP atlas of IIOE (Panikkar 1968) This is quite intriguing since most of the in-situ and satellite chlorophyll a measurements (including the present study) show exceptionally high values in the northern region during winter monsoon period (Banse and McClain, 1986; Chauhan et al., 2007; Balachandran et al., 2008). Then, what could be the possible reason for this relatively low amount of zooplankton biomass in the NEAS during the winter period? Does the seasonal drop in SST (approximately $4-6^{\circ} \mathrm{C}$ ) during the winter period have any role to play in this phenomenon? In this context, it is relevant to consider the results obtained by Jayalakshmy (1984) (based on the pooled data of the IIOE), that zooplankton production is significantly (positively) related to temperature. Similarly, a seasonal study conducted in the Gulf of Kachchhh area showed that the MSP biomass and abundance during December were markedly lesser compared to the collections during February and August (Paulinose et al., 1998). These observations point to a regulatory effect of temperature on zooplankton standing stock in the NEAS. If this could be true, then what would be the fate of the high winter phytoplankton biomass in the north? It is coincidental to notice the occurrence of large number of diatoms floating in the sediment traps, deployed in the winter bloom areas of the Arabian Sea (Sawant and Madhupratap, 1996). This underlines the fact that zooplankton grazing may not be effectively controlling the winter blooms (Sawant and Madhupratap., 1996). This high under grazed winter phytoplankton standing stock could be significantly contributing to the highest carbon fluxes in the northern Arabian Sea (Sarma et al., 2007). However, more work would be needed to understand the extent of temperature regulation on MSP biomass in the northern Arabian Sea.

An analysis of major compositional change in MSP community showed less variation between the northern and southern regions of the EAS during monsoon periods (Madhupratap et al., 1996a; Padmavati et al., 1998). While swarms of salps and ostracods are common in north of $20^{\circ} \mathrm{N}$ during the late winter /early spring period (Paulinose and Aravindakshan, 1977; Ramaswamy et al., 2005), it has only minor impact on secondary production in the southern parts of the NEAS. In general, copepods form the bulk of the zooplankton community in the northern and southern regions followed by chaetognaths (Madhupratap et al., 1996a). In the northern region, species belonging to the major copepod families follow their relative order of abundance; Paracalanidae $(47 \%)>$ Clausocalanidae $(20 \%)>$ Euchaetidae $(11 \%)>$ Eucalanidae $(10 \%)$ during the winter monsoon (Padmavati et al., 1998). In the southeastern Arabian Sea, copepod families follow their order of abundance: Paracalanidae $(52 \%)>$ Eucalanidae $(23.5 \%)>$ Acartiidae $(10.5 \%)>$ Calanidae (10\%) during the summer monsoon (Madhupratap et al., 1992; Madhupratap et al., 
1996a). Although the major copepod families occurring in both regions seems to be more or less same, it is assumed that more than one fold increase in Eucalanid species along the southwest coast of India during the summer monsoon period, may be important in maintaining the high MSP biomass. This assumption is based on the fact that the species of the Family have the highest body size compared to other common pelagic species of copepods in the EAS.

\subsubsection{Spring Intermonsoon}

During the spring intermonsoon, similar to the winter monsoon, northern regions had high biomass compared to the south (Figure 11 e \& f) possibly as a continuance of high phytoplankton stock of the winter convection. The high MSP biomass prevailing in the NEAS during the spring intermonsoon period has been recorded in a few earlier studies including the IIOE (Rao, 1973). Although climatic winter forcing is pronounced during November - February, high concentration of entrained nutrients in the surface waters may persist for a few more months in the northern Arabian Sea, leading to extensive phytoplankton stock in the northern region until the end of March (Banse and McClain, 1986; Dwivedi et al., 2006; Madhu et al., 2008). This could be instrumental in sustaining high MSP biomass throughout the spring intermonsoon period.

Another possible reason for the high MSP biomass in the northern region during the spring intermonsoon period could be the prevalence of an active microbial loop, based on dissolved inorganic carbon originating from the high winter production. Due to weakening of poleward flowing West India Coastal Current during March - April period, the high saline northern Arabian Sea waters, which is known to be rich in DOC (Madhupratap et al., 1996a), occupies the NEAS. However, there are not sufficient data available on the seasonal distribution of DOC in the eastern Arabian Sea to suggest this possibility.

\subsubsection{Geographical and seasonal variation}

\subsubsection{Basin scale}

The comparison of basin scale averages and its statistical significance are shown in Figure 12. Comparison between MSP biomass in the mixed layer and thermocline showed significant variation during different seasons (Figure 12 a). The marked difference in MSP biomass between mixed and thermocline layers are general features in the Arabian Sea (Madhupratap et al., 1996a; Padmavati et al., 1998; Smith and Madhupratap, 2004; Gauns et al., 2005). This is primarily due to the fact that the mixed layer represents the surface ocean layer, which is illuminated optimally and therefore a major part of the total ocean primary productivity takes place in this layer. Most of the environmental forcing and the associated changes have direct impact on the chemistry of this layer that directly gets translated into phytoplankton biomass. 
The most important feature in Figure $12 a$ is the statistically insignificant variability in MSP standing stock in the mixed layer and thermocline layer during different seasons $(p>0.05)$. Similarly, the seasonal difference in the mixed layer of the inshore and offshore regions was also statistically insignificant (Figure 12b). This corroborates with the earlier observation by Madhupratap et al. (1996a) that MSP biomass does not vary seasonally in the EAS. However, it is important to note that the above results were based on comparisons of data for the entire EAS, without considering the well-marked north-south difference in phytoplankton standing stock during different seasons. However, the spatial (inshore-offshore) variability in the mixed and thermocline layers was statistically significant during different seasons (Figure 12b\&c), which represent the low MSP biomass in the offshore regions in most cases.

(Preferred position for Figure 12)

\subsubsection{Regional scale}

The results of seasonal and geographical variation of MSP biomass in the northern and southern regions of the EAS are shown in Figure 13. There was significant seasonal variability in MSP biomass in the mixed and thermocline layer of the northern and southern regions (Figure 13a \& b). Significant seasonal variability in MSP biomass was also found between the northern and southern regions in the mixed and thermocline layers (Figure 13a \& b). This was primarily due to the prominent difference in the phytoplankton biomass occurring in the northern and southern regions during different seasons. This also indicates the difference in the amount of primary carbon available in the northern and southern regions during different seasons in relation to the changes in the climatic and oceanographic features of these regions, as explained earlier.

In the mixed layer of the northern and southern regions, the seasonal variations of MSP biomass were prominent in the inshore and offshore regions (Figures $13 \mathrm{c} \& \mathrm{~d}$ ). This basically represented the marked enhancement in MSP biomass in the inshore regions of the north, during the winter/spring intermonsoon periods and in the inshore regions of the south during the summer monsoon period. However, inshore-offshore variation in MSP biomass was statistically insignificant $(p>0.05)$ in the north whereas it was statistically significant $(p<0.05)$ in the south (Figures $13 c \& d$ ). The former was due to the more dispersion of the high MSP biomass during the winter and spring intermonsoon, resulting in marginal difference in biomass between the inshore and offshore regions during these seasons. On the other hand, MSP biomass accumulation in the south was highly restricted to the inshore region during the summer monsoon period and the offshore region had low biomass during all seasons (Figure $13 \mathrm{~d}$ ).

In the thermocline layer of the north, seasonal inshore- offshore variability was significant $(p<0.05)$, whereas seasonal difference within the inshore and offshore regions were insignificant $(p>0.05)$ (Figure $13 \mathrm{e})$. The significant inshore - offshore variation was due to the relatively high 
biomass accumulation in the inshore during summer monsoon. However, due to more or less comparable biomass in the inshore locations during winter/ spring intermonsoon periods and in the offshore region during summer/winter periods, the seasonal variability was found to be statistically insignificant. In contrast to this, in the thermocline layer of the south, MSP biomass distribution showed significant seasonal $(p<0.05)$ and inshore - offshore variations $(p<0.1)$, even though at a lower level of significance in the latter case. This was basically due to the markedly low MSP biomass during the spring intermonsoon period (Figure $13 \mathrm{f}$ ). The figure 13e-f also shows that, although the magnitude of MSP biomass in the offshore regions of the SEAS is low throughout the year, there is still significant variation during different seasons.

(Preferred position for Figure 13)

The overall pattern of phytoplankton stock in the NEAS shows a prominent increase during peak and late summer monsoon (July-September). If, this high phytoplankton stock subsequently supports a corresponding amount of zooplankton, then there would be a possibility of high MSP biomass in the NEAS during most part of the year, since winter convection also causes high MSP biomass from November to April. However, there is no such possibility of consistently high MSP biomass in the case of SEAS, since, high productivity regimes are localised along the shelf and some parts of the oceanic region during the summer monsoon. Importantly, the plankton productivity pattern presented in this paper follows the distribution of oxygen deficient waters in the EAS, which increases in the northern region and in the shelf waters along the southwest coast of India. The present study also corroborates the recent observation of Sarma (2004), that the plankton production in the EAS is 'net heterotrophic' on an annual scale, and identifies the important role of southeastern Arabian Sea in causing the net heterotrophy in the region.

The contribution of IIOE to the knowledge of zooplankton distribution pattern in the western Arabian Sea has been well recognised (Baars, 1999). The present study confirms that even with all methodological inadequacies, the seasonal and geographical picture of MSP biomass distribution in the EAS provided by IIOE still holds good, probably due to the high sampling resolution. This study points to the need for intensive observations in any marine systems in order to decipher the highly variable plankton distribution pattern.

\section{Conclusions}

This paper re-evaluates the 'paradox of MSP' in the EAS based on intensive observations from 37 to 40 locations. MSP samples collected from mixed and thermocline layers (both together form $\sim 90 \%$ of the total MSP biomass) during different seasons were used for the analysis. We have classified the EAS into (a) northern (north of $\left.15^{\circ} \mathrm{N}\right)$ and southern $\left(15^{\circ} \mathrm{N}\right.$ and south of it) regions. This demarcation was in accordance with the known seasonal shift in monsoon 
characteristics. The chlorophyll a data and images retrieved from SeaWiFS have shown prominently high concentration (av. $1 \mathrm{mg} \mathrm{m}^{-3}$ ) in the northern region for 8 months annually, through winter convection, open ocean upwelling and advection of nutrients from the Arabian coast. On the other hand, the low chlorophyll a content (av. $0.2 \mathrm{mg} \mathrm{m}^{-3}$ ) in the southern region for 7 months annually is largely caused by the thermohaline stratification during the winter and spring intermonsoon periods. The general distribution pattern of MSP biomass was found to be relatively high in the northern region during the winter and spring intermonsoon periods and along the southwest coast of India during the summer monsoon. Analyses of MSP biomass data using Twoway nested ANOVA clearly showed that the 'lack of seasonal and geographical variability of MSP biomass' in the eastern Arabian Sea; proposed by Madhupratap et al., (1996), is the result of poor sampling resolution and comparing the seasonal averages of the entire EAS. They overlooked the well marked seasonal difference in plankton biomass and production in the NEAS and SEAS. The scientific evidences presented in this paper clearly show that the concept of 'paradox of MSP' is not logically applicable for EAS.

\section{Acknowledgements}

We are thankful to Satish. R. Shetye, Director, National Institute of Oceanography, India for the encouragement to publish this work. We thank the Director, Centre for Marine Living Resources and Ecology, Kochi, India for the financial support to the Research Project 'Marine Research Living Resource Assessment Programme' to which the present work is related. We are extremely thankful to Prof. Trevor Platt and Dr. Subha Sathyendranath, who were instrumental to address this topic as a group project work during the NF - POGO training programme 'Calculation of Primary Production and Applications of Remote Sensing to Analysis of Marine Ecosystem

Dynamics' held at National Institute of Oceanography, Regional Centre, Kochi, India during December 2004 to February 2005. This is NIO contribution XXXX

\section{References}

Achuthankutty, C. T., Ramaiah, N., Padmavati, G. (1997). Zooplankton variability and copepod assemblage in the coastal and estuarine waters of Goa along the central west coast of India. Intergoverntal Oceanographic Commission, 1 workshop report number 142 (ed.) A.C. Pierrot-Bults \& S. Vander Spoel, UNESCO, Paris, pp 1 - 11.

Ashjian, C.J., Smith S.L., Flagg, C.N., Mariano, A.J, Behrens, W.J, Lane, P.V., 1994. The influence of a Gulf Stream meander on the distribution of zooplankton biomass in the slope water, the Gulf Stream, and the Sargasso Sea, described using a shipboard acoustic doppler current profiler. Deep-Sea Research 41, 23 - 50.

Baars, M.A., 1994. Monsoons and pelagic systems. Leiden: National Museum of Natural History, 1, pp. 143. 
Baars, M.A., 1999. On the paradox of high mesozooplankton biomass, throughout the year in the western Arabian Sea: Re-analysis of IIOE data and comparison with newer data. Indian Journal of Marine Sciences 28, $125-137$.

Baars, M.A., Oosterhuis, S.S., 1998. Mesozooplankton biomass in the upper $200 \mathrm{~m}$ in and outside the seasonal upwelling areas of the western Arabian Sea. In A.C. Pierrot-Bults \& S. van der Spoel (eds.), Pelagic biogeography ICoPBII. Paris: UNESCO,Intergovernmental Oceanographic Commission, $36-49$.

Balachandran, K.K., Laluraj, C.M., Jyothibabu, R., Madhu, N.V., Muraleedharan, K.R., Vijay John Gerson., Maheswaran, P.A., Mohammed Ashraff, T.T., Nair, K.K.C., Achuthankutty, C.T., 2008. Hydrography \& biogeochemistry of the northwestern Bay of Bengal and the northeastern Arabian Sea during winter monsoon. Journal of Marine Systems (in press).

Banse, K., 1959. On upwelling and bottom trawling off the southwest coast of India. Journal of Marine Biological Association of India 1, 33 - 39.

Banse, K., 1987. Seasonality of phytoplankton chlorophyll in the central and northern Arabian Sea. Deep-Sea Research 4, 713 - 723.

Banse, K., McClain, C.R., 1986. Winter blooms of phytoplankton in the Arabian Sea as observed by the Coastal Zone Colour Scanner. Marine Ecology Progress Series 34, 201 - 211.

Banse, K., Sumitra Vijayaraghavan, Madhupratap, M., 1996. On the possible causes of the seasonal phytoplankton blooms along the southwest coast of India. Indian Journal of Marine Sciences 25, $283-289$.

Bhattathiri, P.M.A., Pant, A., Sawant, S., Gauns, M., Matondkar, S.G.P., Mohanraju, R., 1996. Phytoplankton production and chlorophyll distribution in the eastern and central Arabian Sea in 1994 - 1995. Current Science 71, 869 - 877.

Buitenhuis, E., Le Quere, C., Aumont, O., Beaugrand, G., Bunker, A., Hirst, A., Ikeda, T., et al., 2006. Biogeochemical fluxes through mesozooplankton. Global Biogeochemical Cycles 20, GB 2003, doi: 10.1029/2005GB002511.

Chauhan, P., Nagur, C.R.C., Mohan, M., Nayak, S.P., Navalgund, R.K., 2007 Surface chlorophyll a distribution in the Arabian Sea and Bay of Bengal using IRS P-4 ocean colour monitor satellite data. Current Science 80, $127-129$.

Cowels, T.J., Olson, R.J., Chrisholm, S.W., 1988. Food selection by copepods: discrimination between cells on the basis of food quality. Marine Biology 100, 41 - 49.

Cushing, D.H., 1989. A difference in structure between ecosystems in strongly stratified waters and those that are only weakly stratified, Journal of Plankton Research 11, $1-13$.

Dwivedi, R.M., Raman, M., Parab, S., Matondkar, S.G.P., Nayak, S., 2006. Influence of northeasterly trade winds on intensity of winter bloom in the Northern Arabian Sea, Current Science 90, $1397-1406$. 
Fortier, L., Leggett, W., 1984. Small-scale covariability in the abundance of fish larvae and their prey. Canadian Journal Fish Aquatic Science 41, 502 - 512.

Franks, P.J.S., 1997. Spatial patterns in dense algal blooms. Limnology and Oceanography 42, $1297-1305$

Gauns, M., Madhupratap, M., Ramaiah, N., Jyothibabu, R., Fernandes, F., Paul, J., Prasannakumar, S., 2005. A comparative account of biological productivity characteristics and estimates of carbon fluxes in the Arabian Sea and Bay of Bengal, Deep Sea Research 52, 20032017.

Gaylor, D.W. and Hopper, F.N., 1969. Estimating the degrees of freedom for linear combinations of mean squares by Satterthwaite's formula. Technometrics 11, $691-706$.

Haake, B., Rixen, T., Ittekot, V., 1993. Variability of monsoonal upwelling signals in the deep western Arabian Sea, In Monsoon Biogeochemistry (eds.), Ittekkot. V and Nair. R. R., SCOPE/UNEP Sonderband, 76, 85 - 96.

Hansell, D.A., Peltzer, E.T., 1998. Spatial and temporal variations of total organic carbon in the Arabian Sea, Deep Sea Research 45, 2171 - 2194.

Haq, S.M., Khan, J.A., Chugti, S., 1973. The distribution of zooplankton along the post monsoon and premonsoon periods. In. The Biology of the Indian Ocean (ed.B. Zeitzschel) Springer Verlag, Berlin, $257-272$.

Haridas, P., Menon, P.G., Madhupratap, M., 1980. Annual variations in zooplankton from a polluted coastal environment. Mahasagar - Bulltin of National Institute of Oceanography 13, 239 248.

Herman, A.W., 1983. Vertical distribution patterns of copepods, chlorophyll, and production in northeastern Baffin Bay. Limnology and Oceanography 28, 709 - 719.

Hwang, J.S., Wong C.K., 2005. The China coastal current as a driving force for transporting Calanus sinicus (Copepoda: Calanoida) from its population centres to waters off Taiwan and Hong Kong during the winter northeast monsoon period. Journal of Plankton Research 27, $205-210$.

Jayalakshmi, K.V., 1984. Empirical relationships between phytoplankton and zooplankton biomass in Indian Ocean. Indian Journal of Marine Sciences 13, 19 - 23.

Johansen O.M., Subbaraju, G., Blindheim, J., 1978. Seasonal variations of the oceanographic conditions off the southwest coast of India during 1971- 1975. Fiskeridirektorates Skrifter Serie Haounder - sokelser 18, 247 - 261. 
Jyothibabu, R., Ashadevi, C.R., Madhu, N.V., Sabu, P., Jayalakshmy, K.V., Josia Jacob, Habeebrehman, H., Prabhakaran, P., Balasubramanian T., Nair K.K.C., 2008a. The response of microzooplankton $(20-200 \mu \mathrm{m})$ to coastal upwelling and summer stratification in the southeastern Arabian Sea. Continental Shelf Research. doi:10.1016/j.csr.2007.12.001

Jyothibabu, R., Madhu, N.V., Jayalakshmy, K.V.. Balachandran, K.K., Shiyas, C.A. Martin, G.D., Nair. K.K.C., 2006. Impact of freshwater influx on microzooplankton mediated food web in a tropical estuary (Cochin backwaters e India). Estuarine, Coastal and Shelf Science 69, 505 - 18.

Jyothibabu, R., Madhu, N.V., Maheswaran, P.A., Jayalakshmy, K.V., Nair., K.K.C. , Achuthankutty. C.T., 2008b. Seasonal variation of microzooplankton $(20-200 \mu \mathrm{m})$ and its possible implications on the vertical carbon flux in the western Bay of Bengal. Continental Shelf Research. doi:10.1016/j.csr.2007.12.011.

Jyothibabu, R., Maheswaran, P.A., Madhu, N.V., Mohamed Asharaf, T.T., Gerson, V.J., Venugopal, P., Revichandran, C., Balasubramanian, T., Gopalakrishnan, T.C., Nair, K.K.C., 2004. Differential response of winter cooling on biological production in the northeastern Arabian Sea and northwestern Bay of Bengal. Current Science 87, $783-791$.

Kidwai, S., Amjad, S., 2000. Mesozooplankton: pre - southwest and northeast monsoons of 1993 to 1994 , from the north Arabian Sea, Marine Biology 136, $561-571$.

Kiorbe, T., 1989. Phytoplankton growth rate and nitrogen content: implications for feeding and fecundity in a herbivorous copepod. Marine Ecology Progress Series 55, 229 - 234.

Koppleman, R., Fabian, H., Weikert, H., 2003. Temporal variability of deep sea mesozooplankton in the Arabian Sea. Marine Biology 142, 959 - 970.

Landry, R.L., Brown, L.S., Campbell, L., Cocstantinou, J., Liu, H., 1998. Spatial pattern in phytoplankton growth and microzooplankton grazing in the Arabian Sea during monsoon forcing, Deep Sea Research 45, 2353 - 2368.

Luo, J., Ortner, P.B., Forcucci, D., Cummings, S.R., 2000. Diel vertical migration of mesozooplankton and mesopelagic fish in the Arabian Sea. Deep-Sea Research 47, 1451 - 1473.

Madhu, N.V., 2004. Seasonal studies on primary production and associated environmental parameters in the Indian Exclusive Economic Zone. Ph.D thesis, Cochin University of Science and Technology, Kochi, India.

Madhu, N.V., Jyothibabu, R. Balachandran, K.K., Honey, U.K., Martin, G.D. Vijay, J.G., Shiyas, C.A., Gupta, G.V.M., Achuthankutty. C.T., 2007. Monsoonal impact on planktonic standing stock and abundance in a tropical estuary (Cochin backwaters e India) Estuarine, Coastal and Shelf Science 73, $54-64$.

Madhupratap, M., Haridas, P., 1986. Epipelagic calanoid copepods of the northern Indian Ocean, Oceanologica Acta 9, $105-117$.

Madhupratap, M., Haridas, P., 1990. Zooplankton especially calanoid copepods, in the upper $1000 \mathrm{~m}$ of the southeast Arabian Sea. Journal of Plankton Research 12, $305-321$. 
Madhupratap, M., Nair, S.R.S., Haridas, P., Padmavati, G., 1990. Response of zooplankton to physical changes in the environment: coastal upwelling along central west coast of India, Journal of Coastal Research 6, 413 - 426.

Madhupratap, M., Haridas, P., Ramaiah, N., Achuthankutty, C.T., 1992. Zooplankton of the southwest coast of India: abundance, composition, temporal and spatial variability in 1987. In: Oceanography of Indian Ocean (eds. Desai, B.N) Oxford \& IBH, New Delhi, 99 - 112.

Madhupratap. M., Parulekar A.H., 1993. Biological Processes of Northern Indian Ocean., In. Monsoon Biogeochemistry, (eds). Ittekkot. V and Nair, R.R., SCOPE/UNEP Sonderband 76, 51 83.

Madhupratap, M., Gopalakrishnan, T.C., Haridas, P., Nair, K.K.C., Aravindakshan , P.N., Padmavati, G., Shiney Paul., 1996a. Lack of seasonal and geographic variation in mesozooplankton biomass in the Arabian Sea and its structure in the mixed layer. Current Science $71,863-868$.

Madhupratap, M., Prasannakumar, S., Bhattathiri, P.M.A., Dileep Kumar, M., Reghukumar S., Nair K.K.C., Ramaiah, N., 1996b. Mechanism of the biological response to winter cooling in the northeastern Arabian Sea. Nature 384, 549 - 552.

Madhupratap, M., Nair, K.N.V., Gopalakrishnan, T.C., Haridas, P., Nair, K.K.C., Venugopal, P., Gauns, M., 2001. Arabian Sea oceanography and the fisheries of the west coast of India. Current Science $81,355-361$.

Maheswaran, P.A., Rajesh, G., Revichandran, C., Nair, K.K.C., 2000. Upwelling and associated hydrography along the west coast of India during southwest monsoon, 1999, Proceedings of the Fifth Pacific Ocean Remote Sensing Conference (PORSEC) II, $873-878$.

Maheswaran, P.A., 2004. Mixed layer characteristics and hydrography off the west and east coasts of India. Ph.D thesis, Cochin University of Science and Technology, Kochi, India. pp. 203.

Mann, K.H., 1993. Physical Oceanography, food chains, and fish stocks: a review. ICES Journal of Marine Sciences 50, $105-119$.

Mathew, K.J., Naomi, T.S. Antony, G. Vincent, D. Anilkumar, R. Solomon. K., 1990. Studies on zooplankton biomass and secondary and tertiary production of the EEZ of India. in Mathew, K.S. (Ed.), Proc. First Workshop Scient. Results. FORV Sagar Sampada, Central Marine Fisheries Research Institute, Cochin. 59-69.

Mizobata, K., Saito, S., 2004. Variability of Berring Sea eddies and primary productivity along the shelf edge during $1998-2000$ using satellite multi scanner remote sensing. Journal of Marine Systems 50, $101-111$.

Muraleedharan, P.M., Prasannakumar, S., 1996. Arabian Sea upwelling - A comparison between coastal and open ocean regions. Current Science 71, 842 - 846. 
Nair, R.R., Ittekot, V., Manganini, S.J., Ramaswami, V., Haake, B., Degens, E.T., Desai, B.N., Honjo, S., 1989. Increased particle flux to the deep ocean related to monsoons. Nature 338, $749-$ 751.

Nair, S.R.S., Devassy, V.P., Madhupratap, M., 1992. Blooms of phytoplankton along the west coast of India associated with nutrient enrichment and the response of mesozooplankton. Science of the Total Environment, Supplement, Elsevier Science Publishers B.V., Amsterdam, 819 - 828.

Naqvi, S.W.A., 1987. Some aspects of the oxygen-deficient conditions and denitrification in the Arabian Sea. Journal of Marine Research 45, 1049 - 1072.

Naqvi, S.W.A., Naik, H., Pratihary, A., D' Souza, W., Narvekar, P.V., Jayakumar, D.A., Devol, A.H., Yoshinari. T., Saino, T., 2006. Coastal versus open-ocean denitrification in the Arabian Sea. Biogeosciences Discussions, 3, 665 - 695, 2006. www.biogeosciences-discuss.net/3/665/2006/

Oullet P, Lefaivre D., 1994. Vertical distribution of northern shrimp (Pandalus borealis) larvae in the Gulf of St. Lawrence; implications for trophic interactions and transport. Canadian Journal of Fisheries and Aquatic Sciences 51,123 - 132

Padmavati, G., Haridas, P., Nair, K.K.C., Gopalakrishnan, T.C., Shiney, P., Madhupratap, M., 1998. Vertical distribution of mesozooplankton in the central and eastern Arabian Sea during the winter monsoon. Journal of plankton Research 20, $343-354$.

Panikkar, N.K., 1968. International Indian Ocean Expedition, Plankton Atlas, Vol.1, Fasc.1, Maps on total MSP biomass in the Arabian Sea and Bay of Bengal, CSIR, New Delhi, 22 pp.

Parsons, T., Kessler, T.A., 1986. Computer model analysis of pelagic ecosystems in estuarine waters. In the role of freshwater outflow in coastal marine ecosystems. (ed. S. Skrestet.), Berlin: Springer-Verlag. 161 - 182.

Paulinose, V.T Aravindakshan, P.N., 1977. Zooplankton biomass, abundance and distribution in the north and northeastern Arabian Sea. Proccedings of .Symposium on Warm Water Zooplankton, National Institute of Oceanography, Goa, 132 - 136.

Paulinose, V.T, Devi, C.B.L., Nair, V.R., Ramaiah, N., Gajbhiye, S.N., 1998. Zooplankton standing stock and diversity in the Gulf of Kachchh with special reference to larvae of decapod and pisces. Indian Journal of Marine Sciences 27, 340 - 345.

Pechen-Finenko, C.A., 1987. The nutritive value of the detritus for the marine plankton animals. In. Production et Relations Trophiques dans les Ecosystems marins, Coll.Franco-Sovietique.Yalta, IFREMER Act. Coll n 5 pp. 171 - 180.

Pineda, J., 1991. Predictable upwelling and the shoreward transport of planktonic larvae by internal tidal bores. Science 253, $548-551$.

Postel, L., Fock, H., Hagen, W., 2000. Biomass and abundance, ICES Zooplankton Methodology manual (eds) Harris R.P., Wiebe. P.H., Leiz. J., Skjoldal et al, Academic Press, $193-213$. 
Poulet, S.A., Marsot, P., 1978. Chemosensory grazing by marine calanoid copepods (Arthropoda: Crustacea). Science 200, $1403-1405$.

Prakash, S., Ramesh, R., 2007. Is the Arabian Sea getting more productive? Current Science 92, $667-671$.

Prasannakumar, S., Madhupratap, M., Dileepkumar, M., Muraleedharan, P.M., de souza, S.N., Gauns, M and Sarma, V.V.S.S., 2001. High biological productivity in the central Arabian Sea during the summer monsoon driven by Ekman pumping and lateral advection. Current Science 81, 1633 - 1638.

Prasannakumar, S., Narvekar, J., Kumar, A., Shaji, C., Anand. P., Sabu, P., Rijomon, G., Josia, J., Jayaraj, K.A., Radhika, A., Nair, K.K.C., 2004. Intrusion of the Bay of Bengal water into the Arabian Sea during winter monsoon and associated chemical and biological response Geophysical Research Letters 31, 4 pp.

Prasannakumar, S., Prasad, T.G., 1996. Winter cooling in the northern Arabian Sea. Current Science 71, 834 - 841.

Qasim, S.Z., 2003. Indian Estuaries. Allied Publication Pvt. Ltd., Heriedia Marg, Ballard Estate, Mumbai, $259 \mathrm{pp}$.

Raj, I.D., Ramamithram, C.P.,1981. Distribution of mesozooplankton biomass, fish eggs and larvae along the west coast of India. Journal of the Marine Biological Association of India 23, 86 140.

Ramaswamy, V., Nagender Nath, B., Vethamony, P., Illangovan, D., 2007. Source and dispersal of suspended sediment in the macro-tidal Gulf of Kachchh. Marine Pollution Bulletin 54, 708 - 719.

Ramaswamy, V., Sarin, M.M. Rengarajan, R., 2005. Enhanced export of carbon by salps during the northeast monsoon period in the northern Arabian Sea. Deep-Sea Research 52, 1922 - 1929.

Rao, T.S.S., 1973. Mesozooplankton studies in the Indian Ocean. In B. Zeitzschel \& S. A. Gerlach (eds.), The biology of the Indian Ocean. Berlin: Springer-Verlag. 243 - 256.

Rao, V.R., Rao, B.R., 1995. Provenance and distribution of clay minerals in the sediments of the western continental shelf and slope of India. Continental Shelf Research 15, 1757 - 1771.

Rixen, T., Haake, B., 1993. Fluxes and decomposition of organic matter in the western Arabian Sea: Aminoacids and Hexosamines. In. Monsoon Biogeochemistry, (eds). Ittekkot. V and Nair. R. R., SCOPE/UNEP Sonderband 76, $113-130$.

Sanilkumar, K.V., Hareeshkumar, P.V., Joseph, J., Panigrahi, J.K., 2003. Arabian Sea mini warm pool during May 2000. Current Science 86, $180-184$. 
Saravanane, N., Nandakumar, K., Durairaj, G., Nair, K.V.K., 2000. Plankton as indicators of coastal water bodies during south-west to north-east monsoon transition at Kalpakkam. Current Science 78, 173 - 176.

Sarma, V.V.S.S., 2004. Net plankton community production in the Arabian Sea based on oxygen mass balance model. Global Biogeochemical Cycles, 18, GB4001, doi:10.1029/2003GB002198,2004.

Sawant, S., Madhupratap, M., 1996. Seasonality and composition of phytoplankton in the Arabian Sea. Current Science 71, 869 - 873.

Shankar, D., Vinayachandran, P.N., Unnikrishnan, A.S., 2002. The monsoon currents in the north Indian Ocean. Progress in Oceanography 52, 63-120.

Shetye, S.R., Shenoi, S.S.C., Antony, M.K., Kumar K.K., 1985. Monthly mean wind stress along the coast of north Indian Ocean. Proceedings of the Indian Academy of Sciences 94, 129-137.

Sladecek, V., 1958. A note on the phytoplankton zooplankton relationship, Ecology 39, 547 - 549.

Smith, S.L., Madhupratap, M., 2005. Mesozooplankton of the Arabian Sea: Patterns influenced by seasons, upwelling and oxygen concentrations. Progress in Oceanography 65, $214-239$.

Smitha, B.R., Sanjeevan, V.N., Vimalkumar, K.G., Revichandran. C., 2007. On the Upwelling off the Southern Tip and along the West Coast of India. Journal of coastal Reseach. DOI: 10.2112/060779 .

Smyth, T.J., Miller, P.I., Groom, S.B., Lavender, S.J., 2001. Remote sensing of sea surface temperature and chlorophyll during Langrangian experiments at the Iberian margin. Progress in Oceanography 51, $269-281$.

Sokal, R.R., Rohlf, J., 1981. Biometry, The Principles and Practice of Statistics in Biological Research. $2^{\text {nd }}$ edition. W.H. Freeman and Company, New York. 1 - 840.

Stoecker, D.K., and Egloff, D.A., 1987. Predation of Acartia tonsa on planktonic ciliates and rotifers. Journal of Experimental Marine Biology and Ecology 110, 53 - 68.

Stoecker, D.K., Capuzzo, J.M., 1990. Predation on protozoa: its importance to zooplankton. Journal of Plankton Research 12, 891 - 908.

Swallow, J., 1984. Some aspects of the physical oceanography of the Indian Ocean, Deep-Sea Research 25, 31, $639-650$.

Thiébaut, E., 1996. Distribution of Pectinaria koreni larvae (Annelida: Polychaeta) in relation to the Seine River plume front (eastern English Channel). Estuarine Coastal and Shelf Science 43, $383-$ 397. 
Wishner, K.F., Gowing, M.M., Gelfman, C., 1998. Mesozooplankton biomass in the upper $1000 \mathrm{~m}$ in the Arabian Sea: Overall seasonal and geographic patterns and relationship to oxygen gradients. Deep-Sea Research 45, 2405 - 2432.

Yentsch, C.S., Phinney, D.A., 1992. The effect of wind direction and velocity on the distribution of phytoplankton chlorophyll a in the western Arabian Sea. In. Oceanography of the Indian Ocean. (eds. Desai, B.N) Oxford \& IBH, New Delhi, $57-66$.

Yentsch, C.S., Phinney, D.A., 1995. Two pathways of primary production induced by monsoon wind forcing. In. Arabian Sea: Living Marine Resources and the Environment. Thomson, M.F., Tirmizi, N. M. (eds.). Vangard Books, Lahore, Pakistan, 469 - 478. 


\section{Figure captions}

Figure 1 - (a) IIOE station locations in the eastern Arabian Sea, mesozooplankton biomass distribution during (b) summer monsoon and (c) winter monsoon: $\mathrm{L}-$ low; $\mathrm{H}$ - high (adapted from Panikkar, 1968).

Figure 2 - Locations of zooplankton sampling during JGOFS India (redrawn from Madhupratap et al., 1996a).

Figure 3 - Mesozooplankton sampling locations. The line around $16^{\circ} \mathrm{N}$ demarcate the geographical area considered for the region scale analysis.

Figure 4 - (a) The pattern of wind direction during the monsoon periods (b) schematic picture of the coastal circulation in the Arabian Sea and Bay of Bengal during monsoon periods based on Shankar et al., 2002. WICC -West India Coastal Current, LL - Lakshadweep Low, LH Lakshadweep high, SMC - Summer Monsoon Current, EICC - East India Coastal Current, WMC - Winter Monsoon Current (c) typical seasonal trend in the circulation pattern as evident in the monthly mean salinity distribution in Levitus climatology.

Figure 5 - Schematic representation of the flow regimes and the physical forcing that fertilizes the central Arabian Sea during the summer monsoon. Open arrows show the lateral advection from the Somalia and Arabia upwelling system, which transports nutrient-rich waters to the central Arabian Sea. Thin dark arrows show the prevailing flow in summer. Long open arrow with bold face is the atmospheric Findlater Jet, which extends from the tip of Somalia to Gujarat, India. The positive (negative) wind-stress curl north (south) of this jet drives the cyclonic (anticyclonic) circulation in the sea, which is indicated by the anticlockwise (clockwise) arrow; the dark, short arrows out of (into) it show the associated divergence (convergence). The right-hand side of the box shows the climatological mean thermal structure for August along $64^{\circ} \mathrm{E}$ based on Levitus' 16 data, which shows the northward shoaling of isotherms (Redrawn from Prasannakumar et al., 2001).

Figure 6 - SeaWiFS monthly mean images showing the seasonal difference in chlorophyll a in the north and south regions of the eastern Arabian Sea. 
Figure 7 - Monthly mean chlorophyll a during the entire time span of the cruises (trend line shows the mean).

Figure 8 - Monthly mean SST $\left({ }^{\circ} \mathrm{C}\right.$ ) during the entire time span of the cruises (trend line shows the mean).

Figure 9 - Wind speed over the time span of MSP sampling period.

Figure 10 - SeaWiFs images representing the MSP sampling period.

Figure 11 - Seasonal distribution of mesozooplankton biomass (g drywt. $1000 \mathrm{~m}^{-3}$ ) during the (a\&b) summer monsoon, (c\&d) winter monsoon and (e\&f) spring intermonsoon seasons.

Figure 12 - Basin scale comparison of MSP biomass in the (a) mixed layer and thermocline layer (b) inshore and offshore regions of the mixed layer and (c) inshore and offshore regions of the thermocline layer.

Figure 13 - Regional Scale comparison of MSP biomass in the (a) mixed layer (b) thermocline layer (c) inshore - offshore variation in the mixed layer of the north, (d) inshore - offshore variation in the mixed layer of the south and (e) inshore - offshore variation in the thermocline of the north (f) inshore - offshore variation in the thermocline of the south.

*conditions for Satterthwaites approximation not satisfied. Hence simple test is applied 


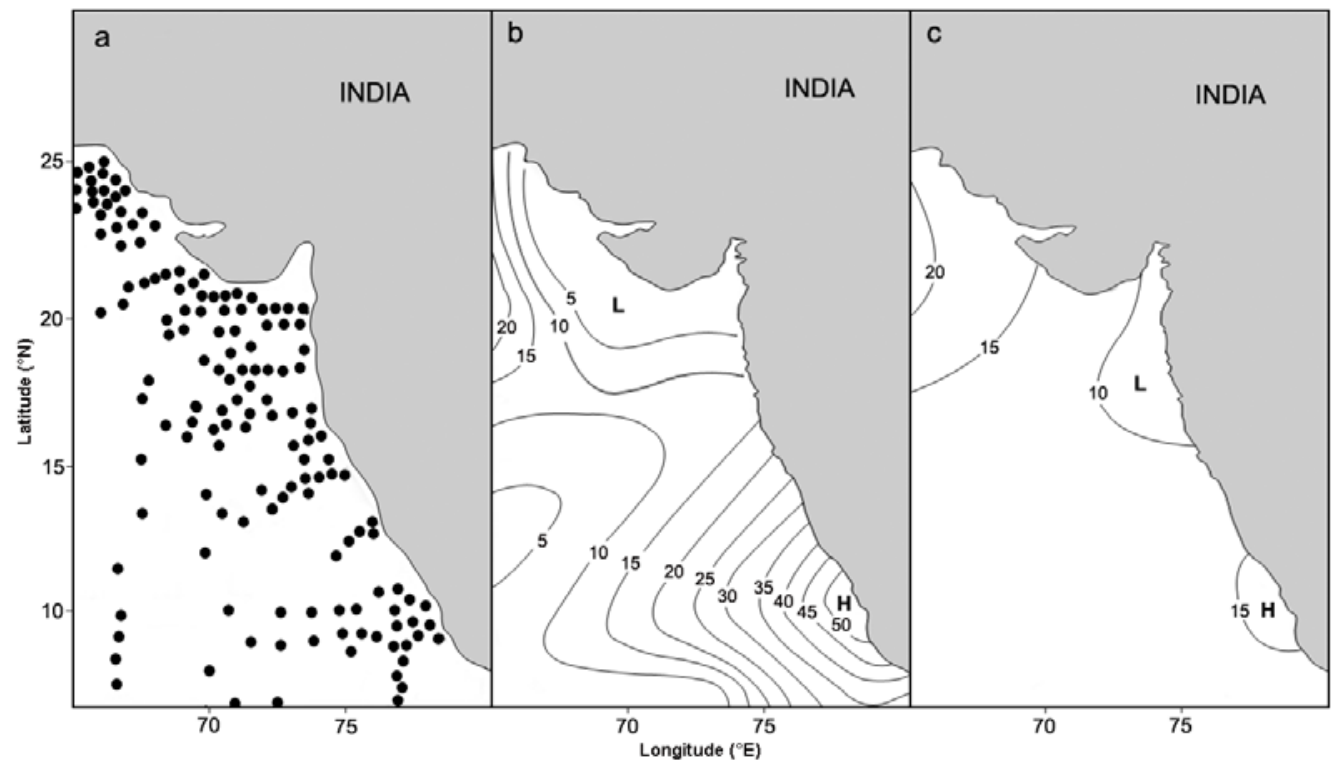

Figure 1 


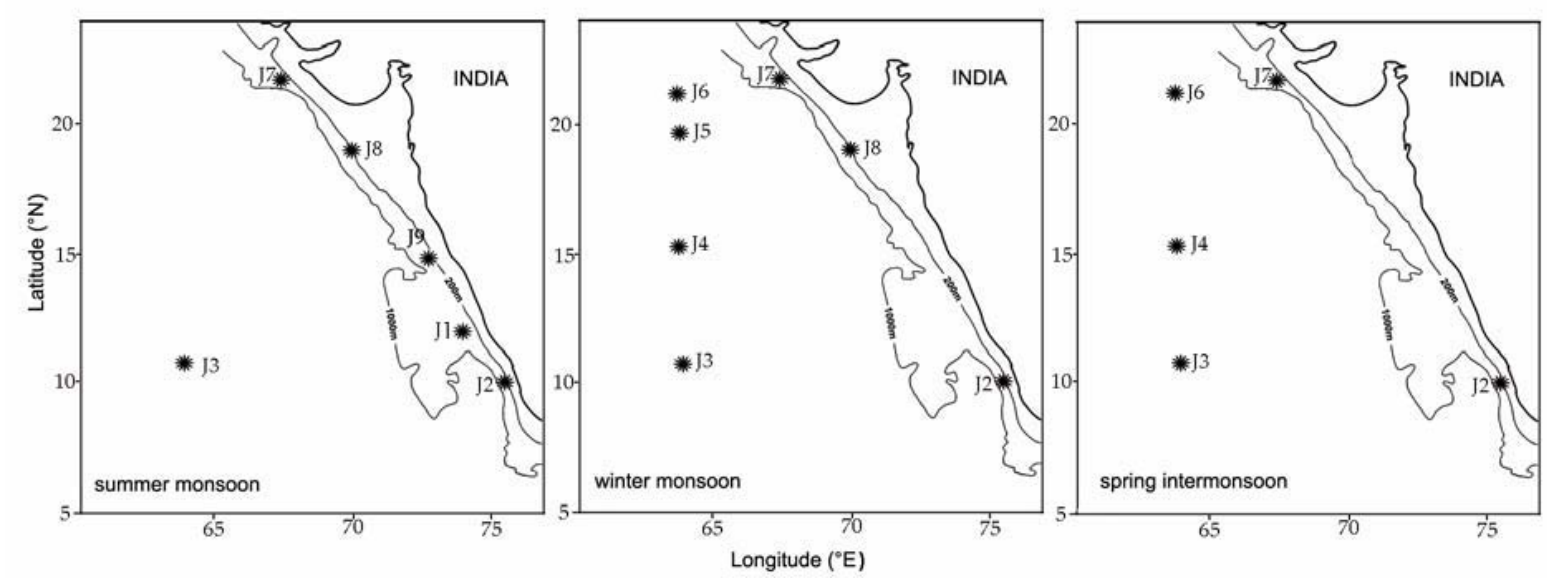

Figure 2 


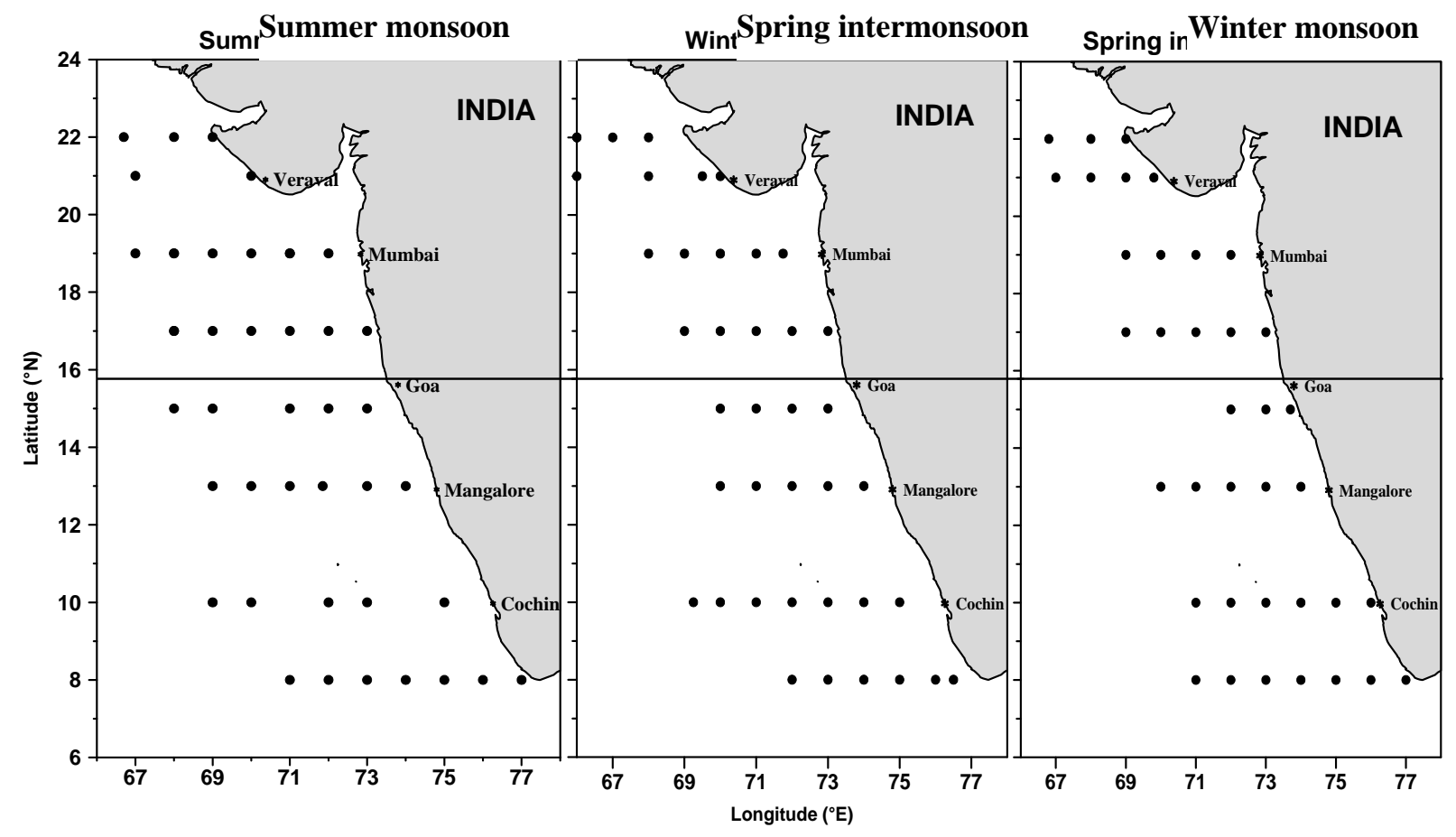

Figure 3 

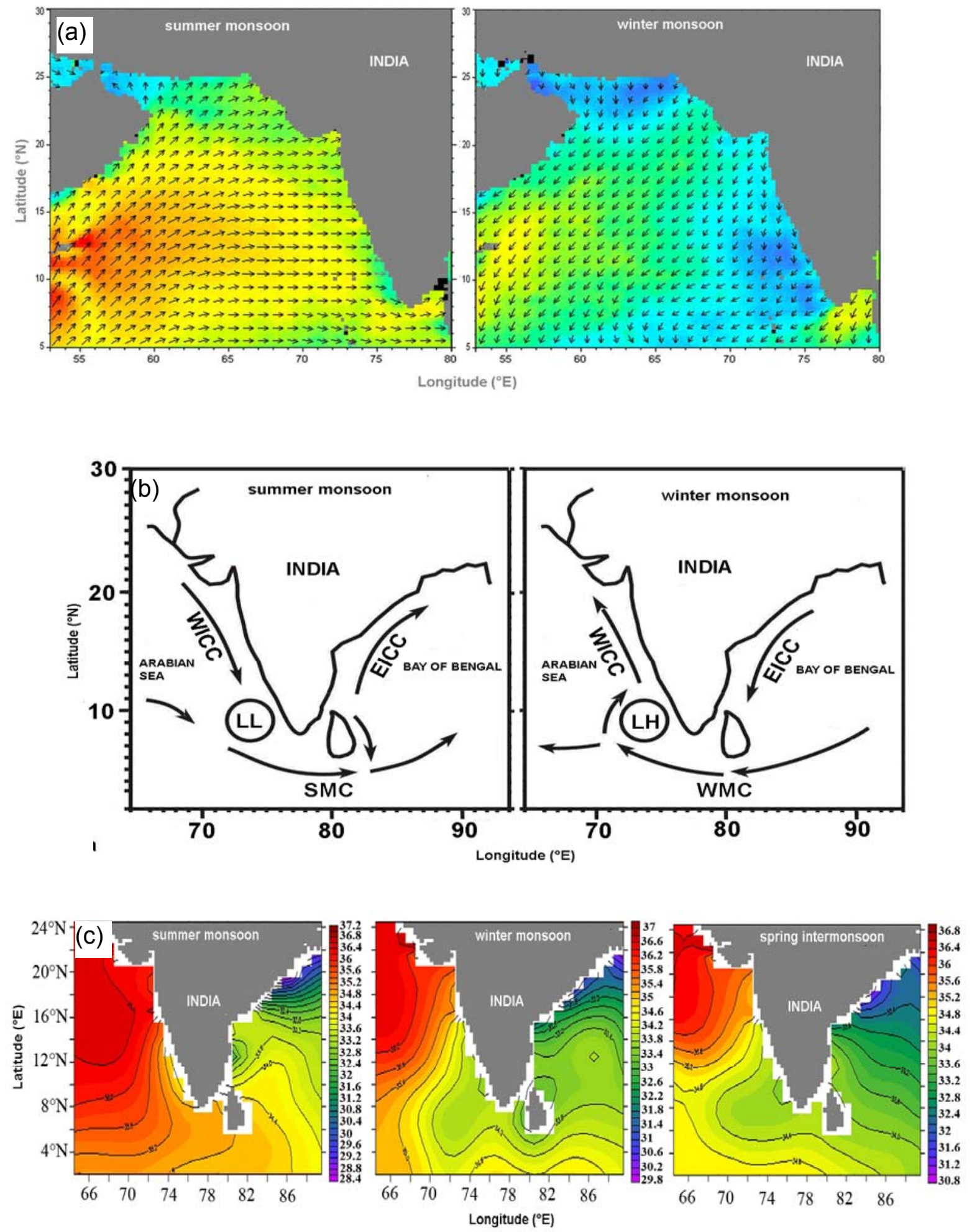

Figure 4 


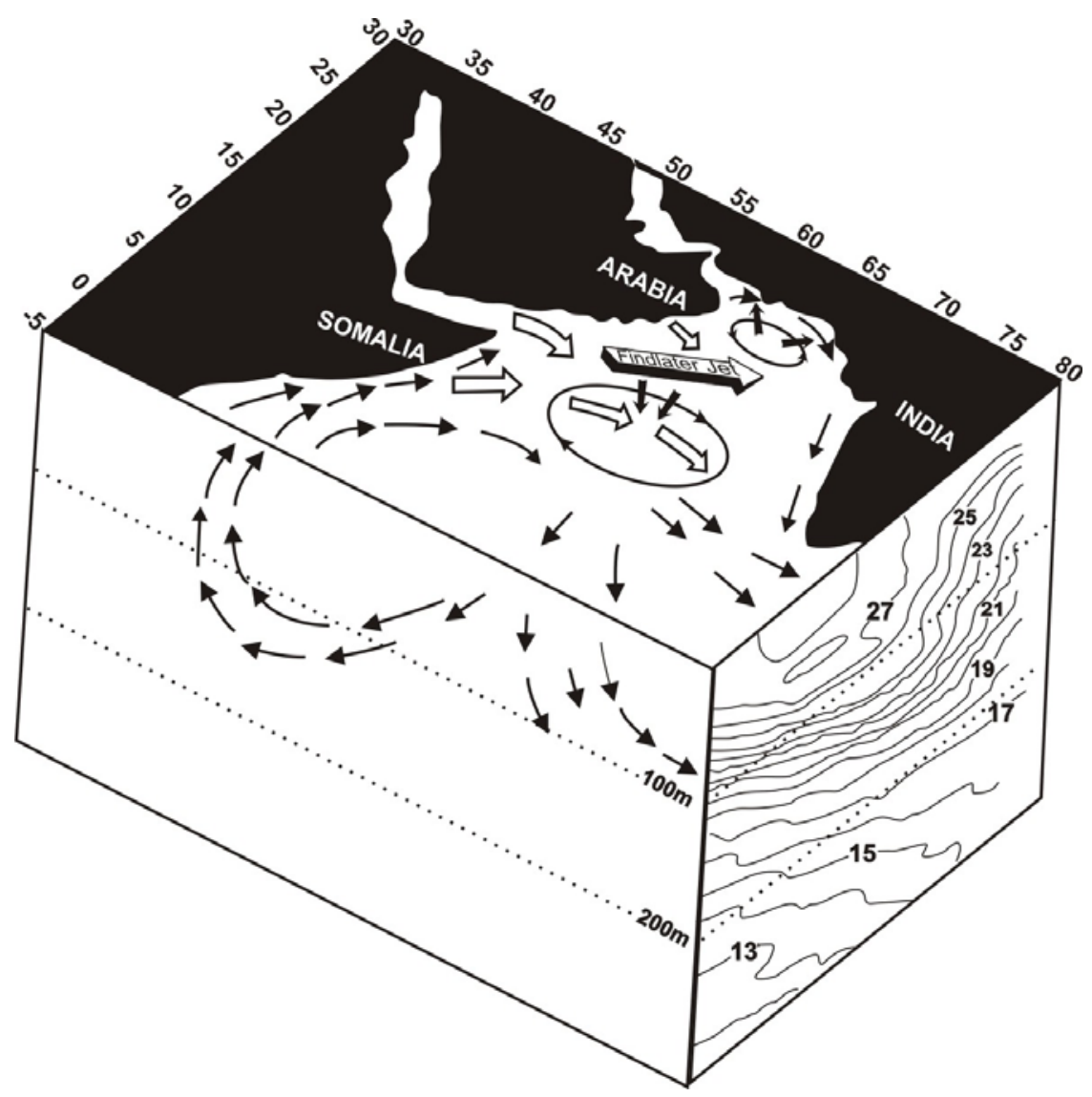

Figure 5 


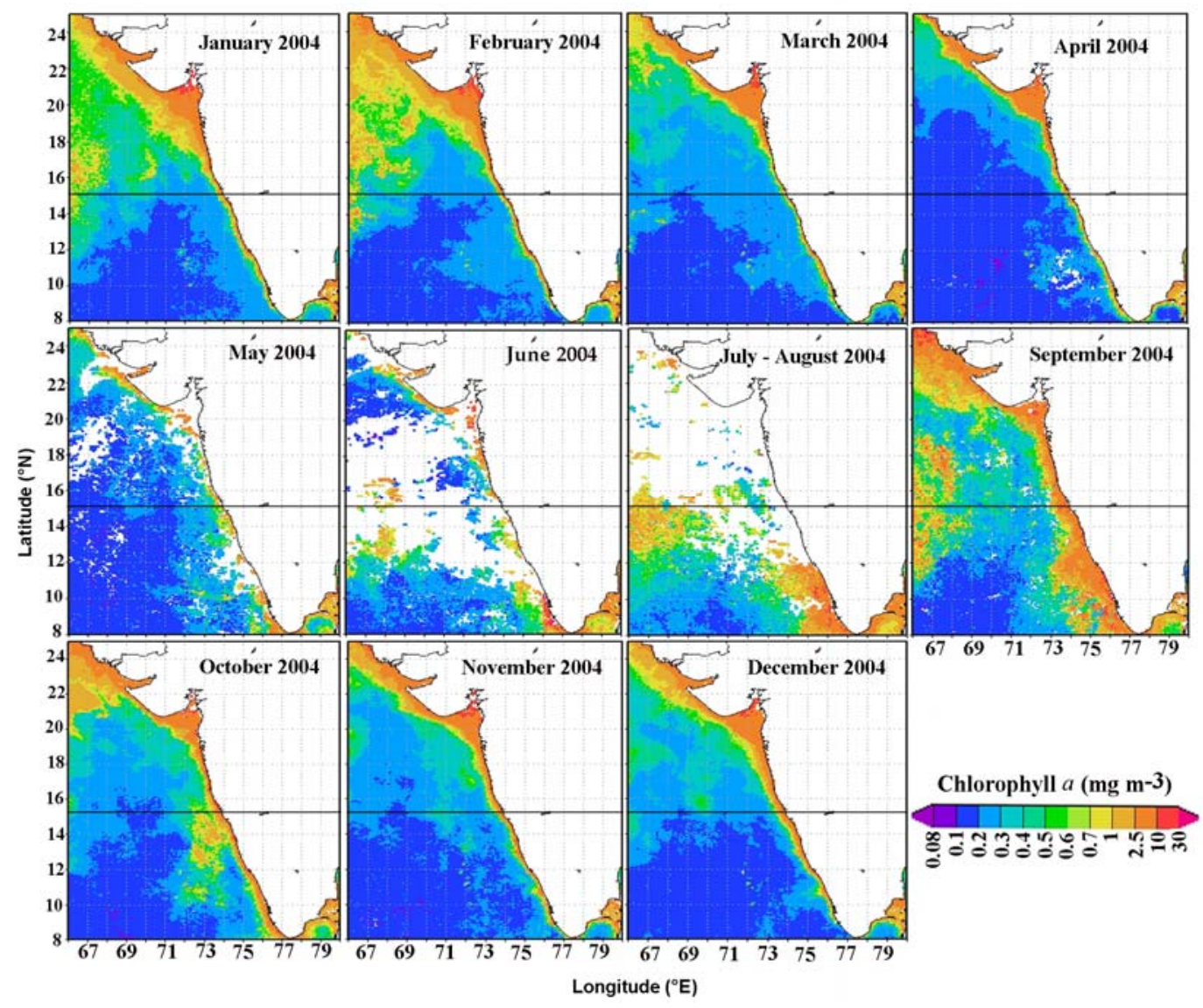

Figure 6 


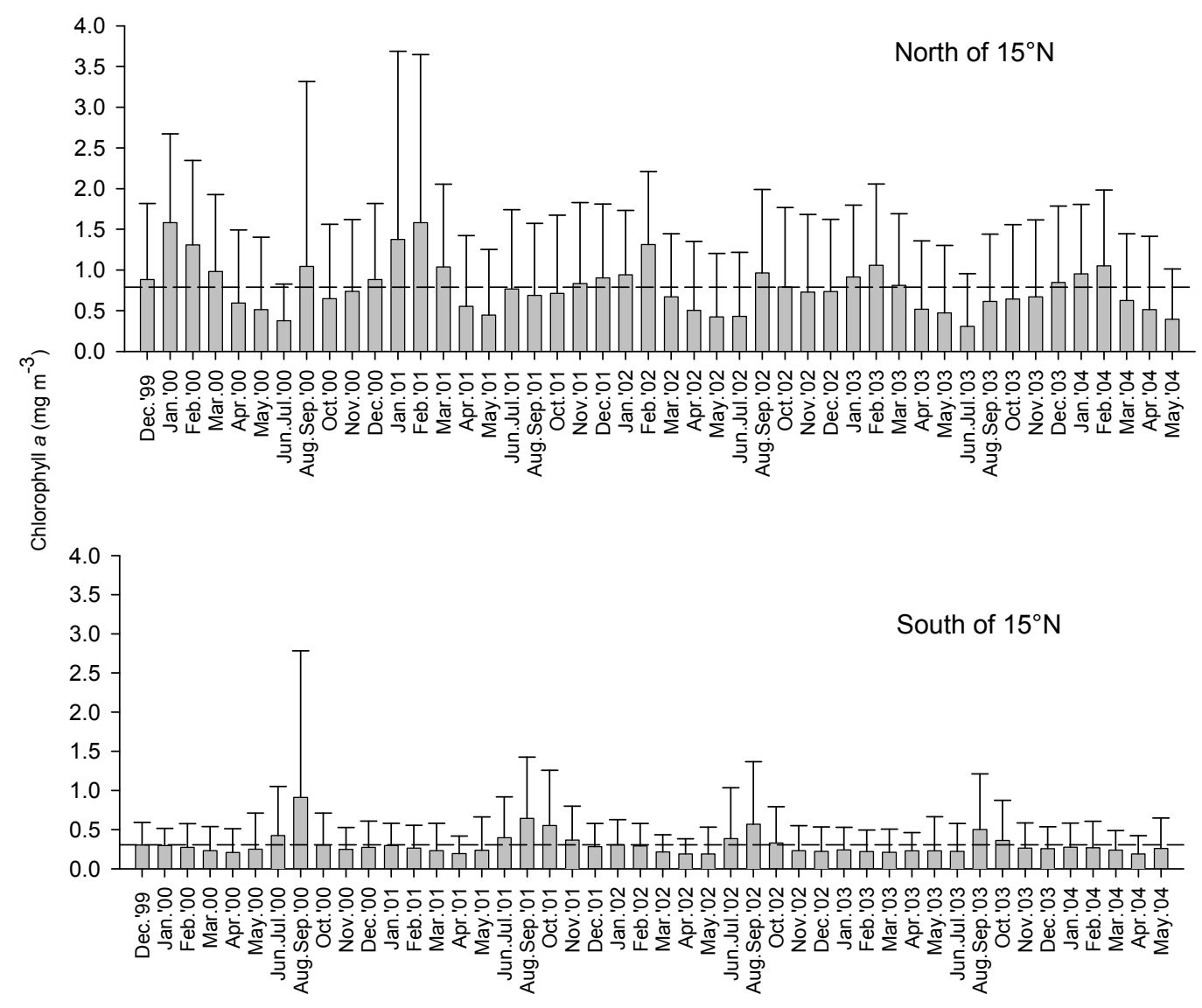

Figure 7 


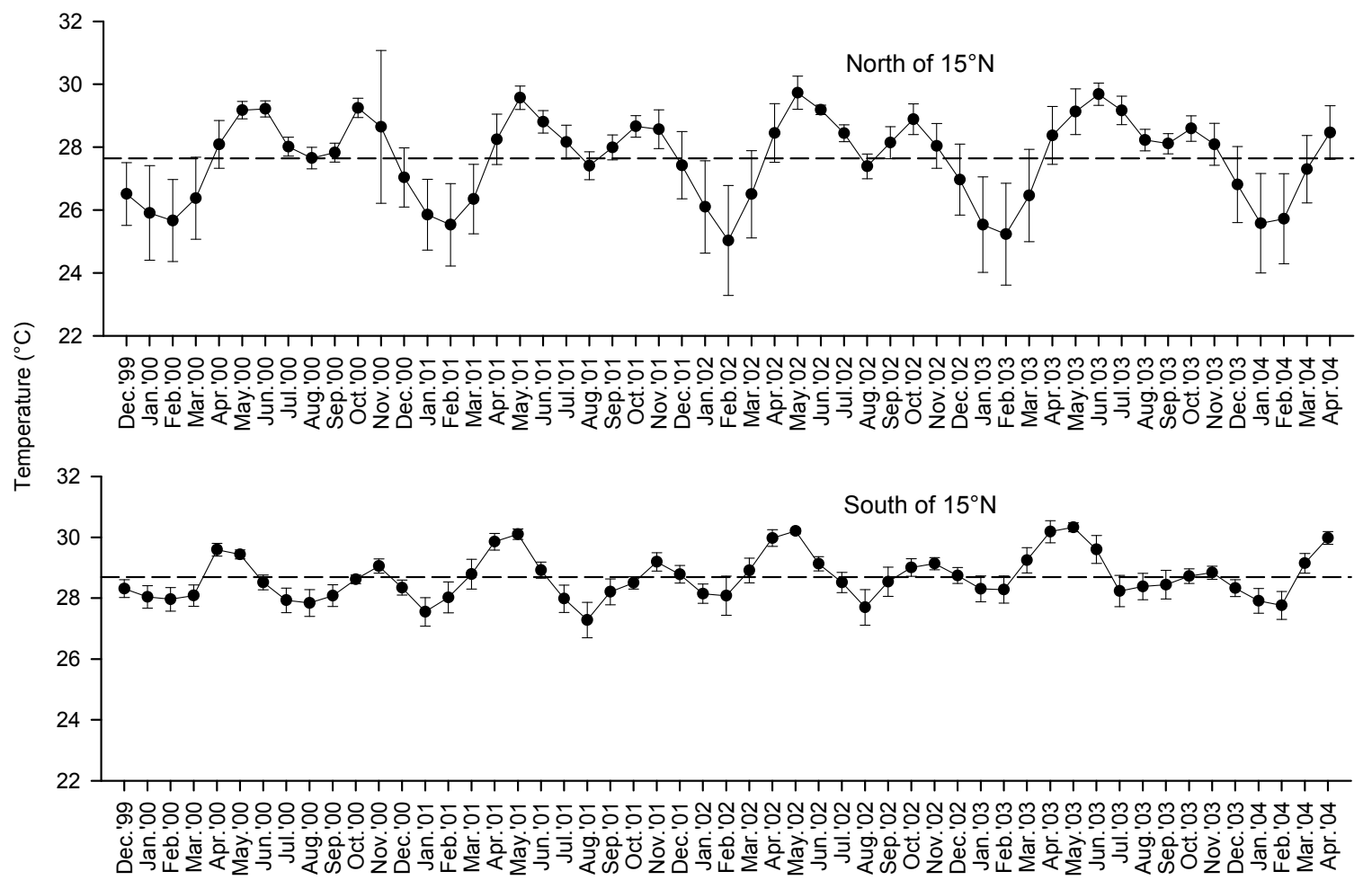

Figure 8 


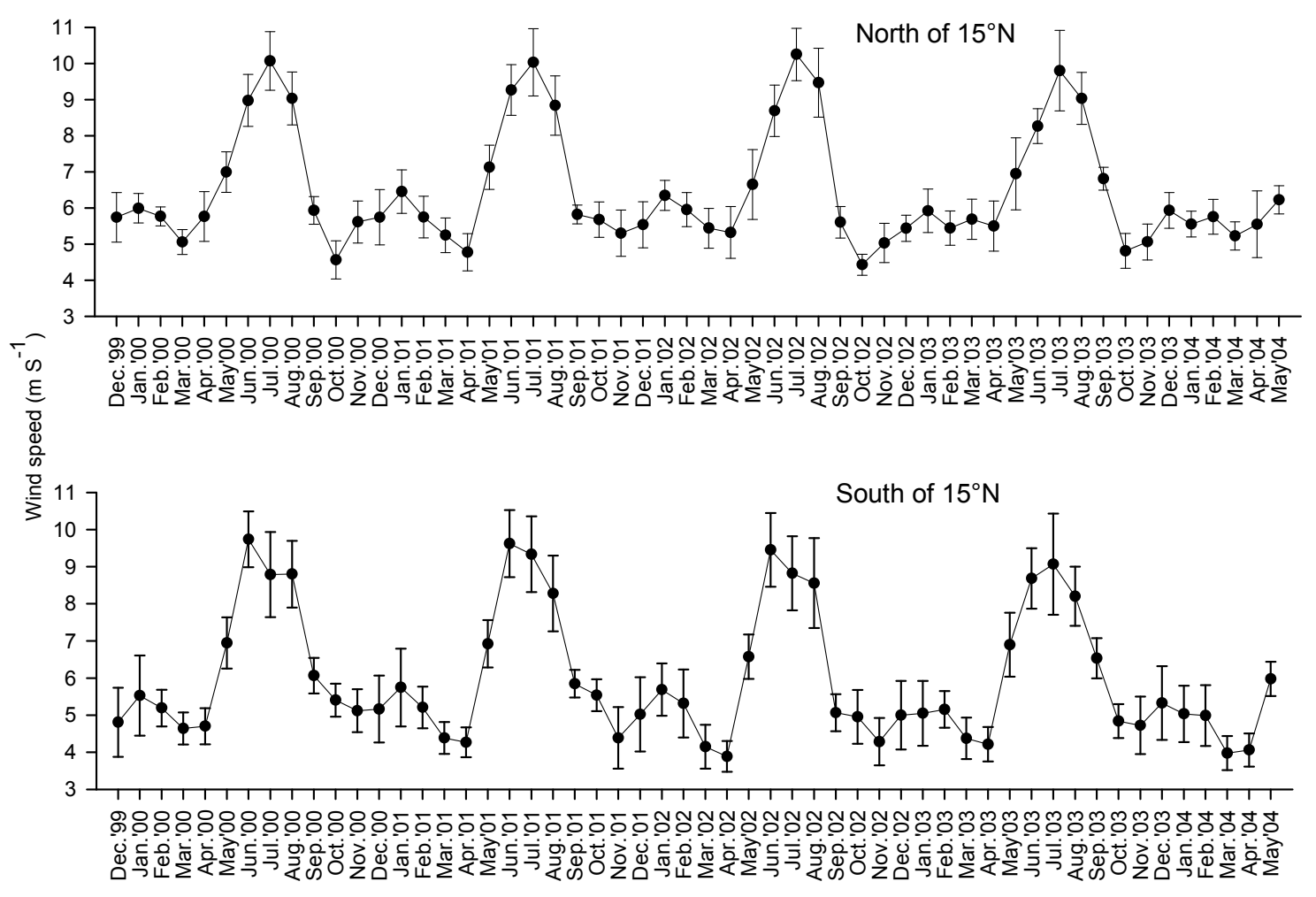

Figure 9 


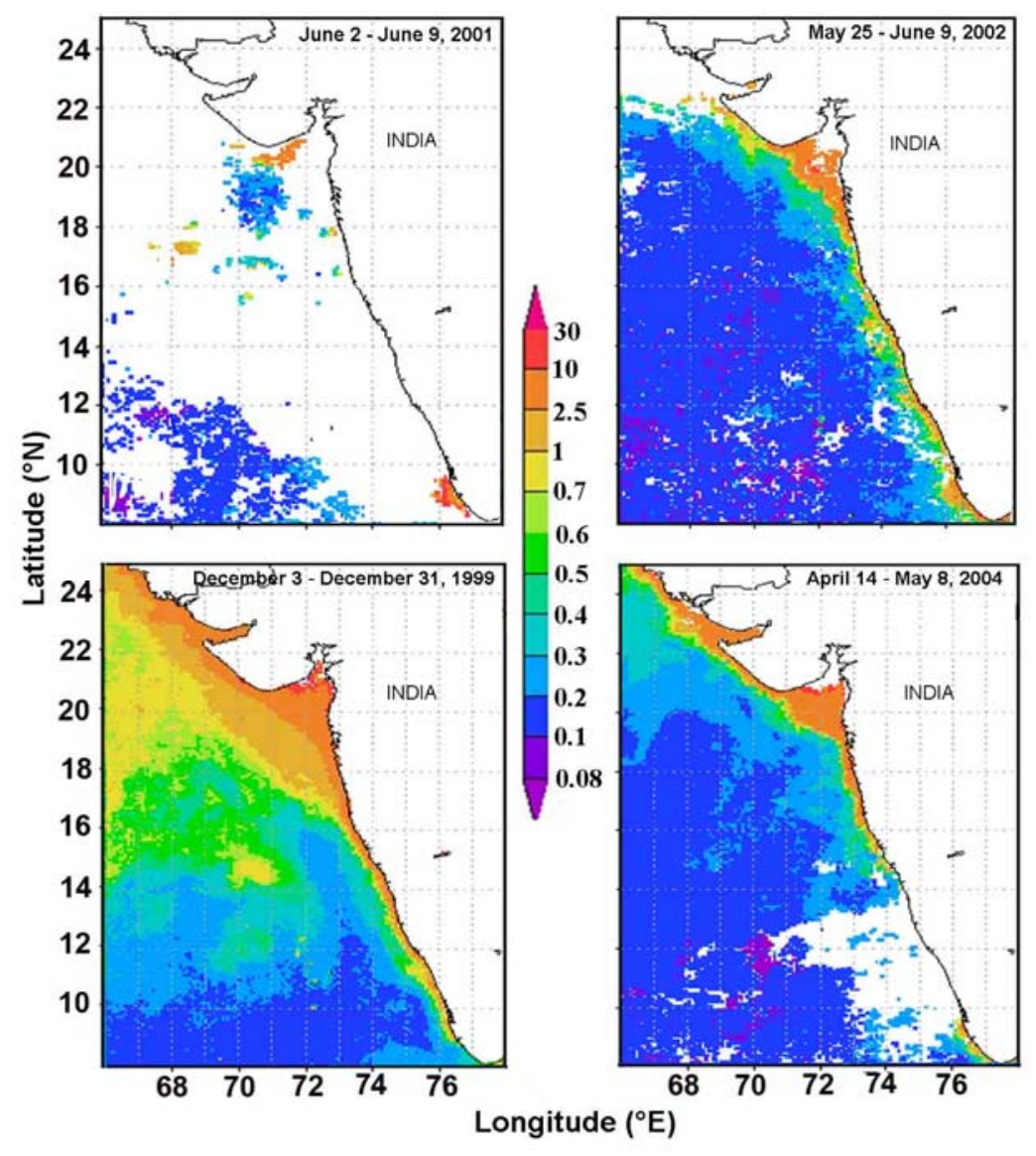

Figure 10 


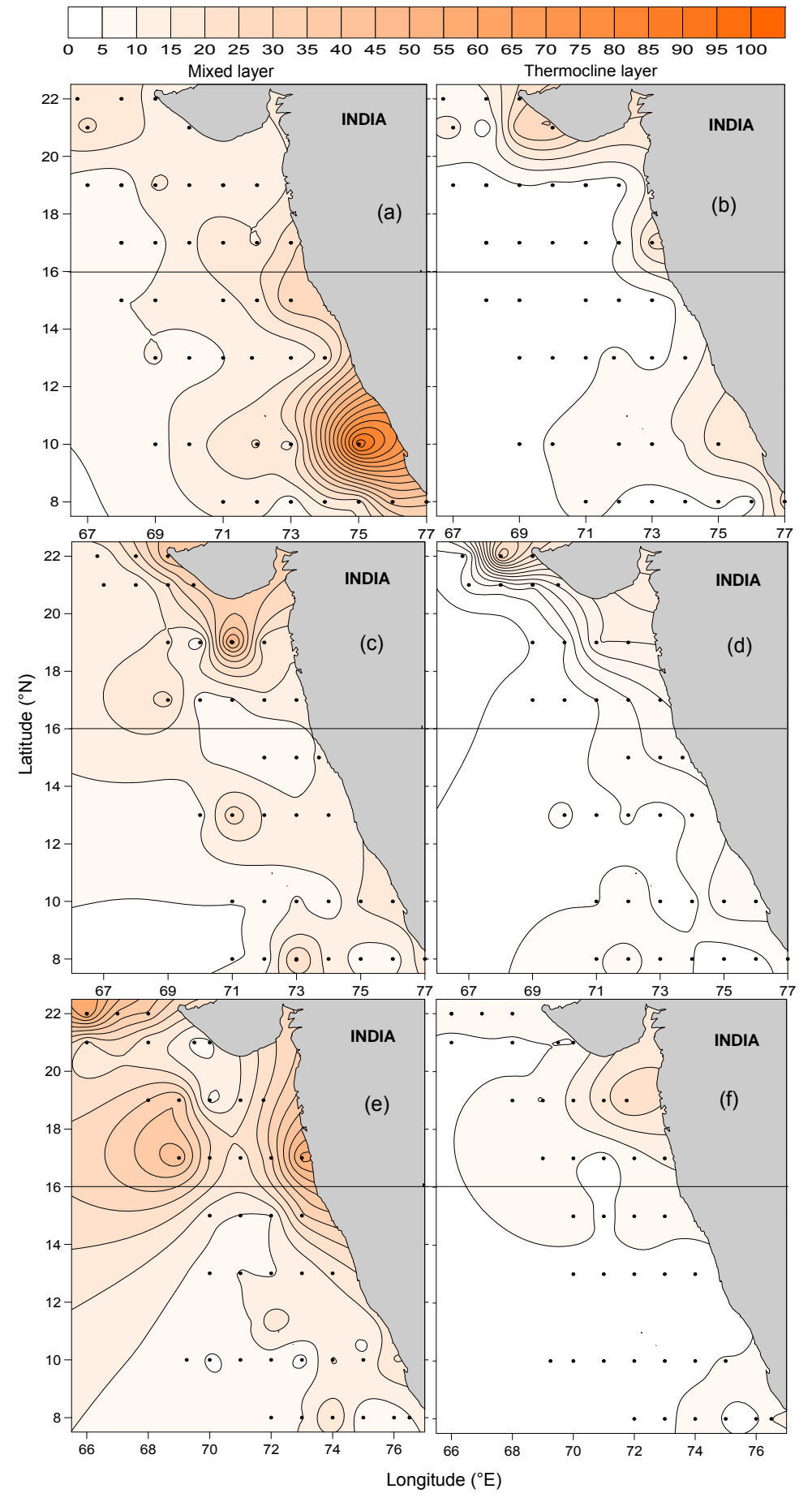

Figure 11 

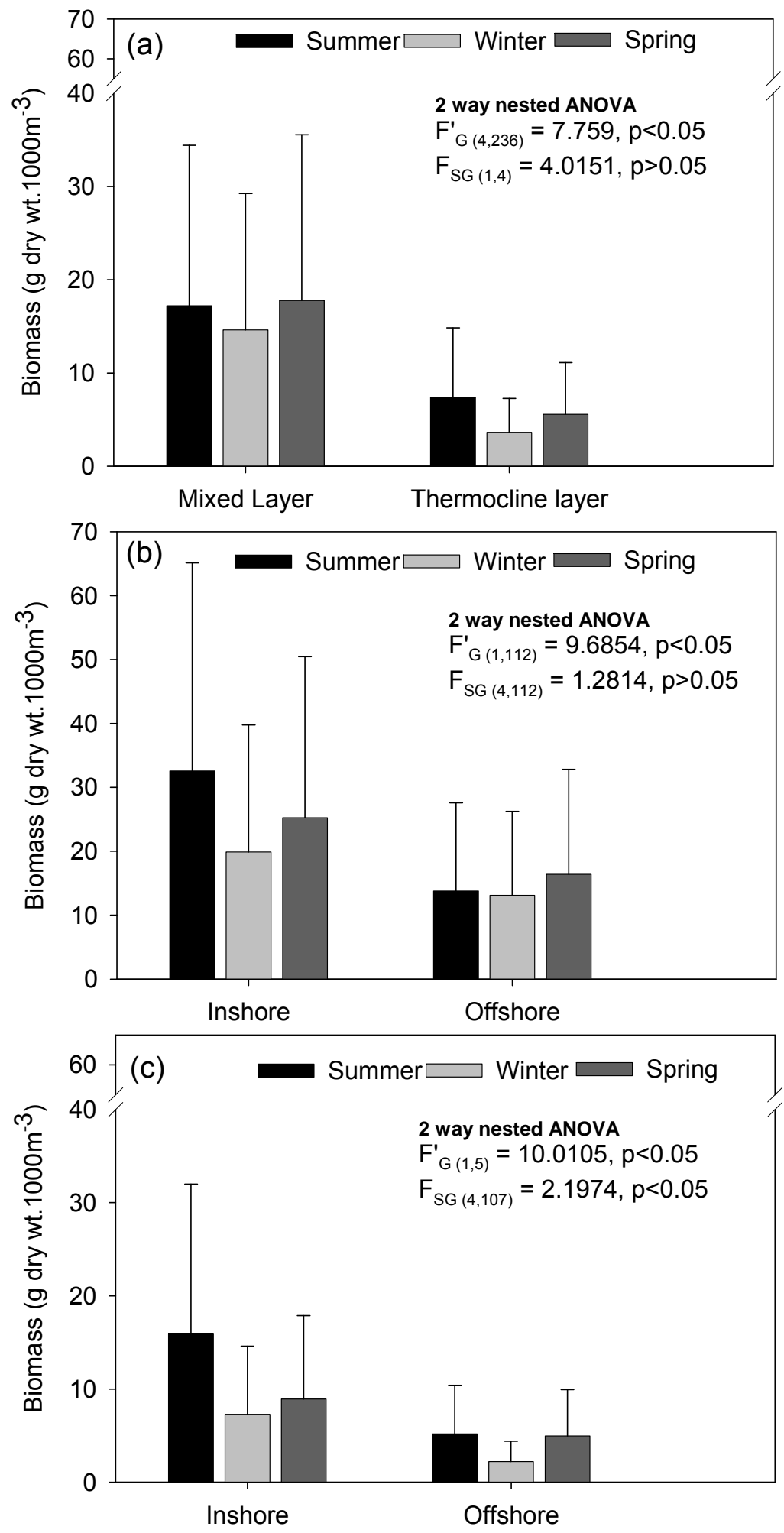

Figure 12 

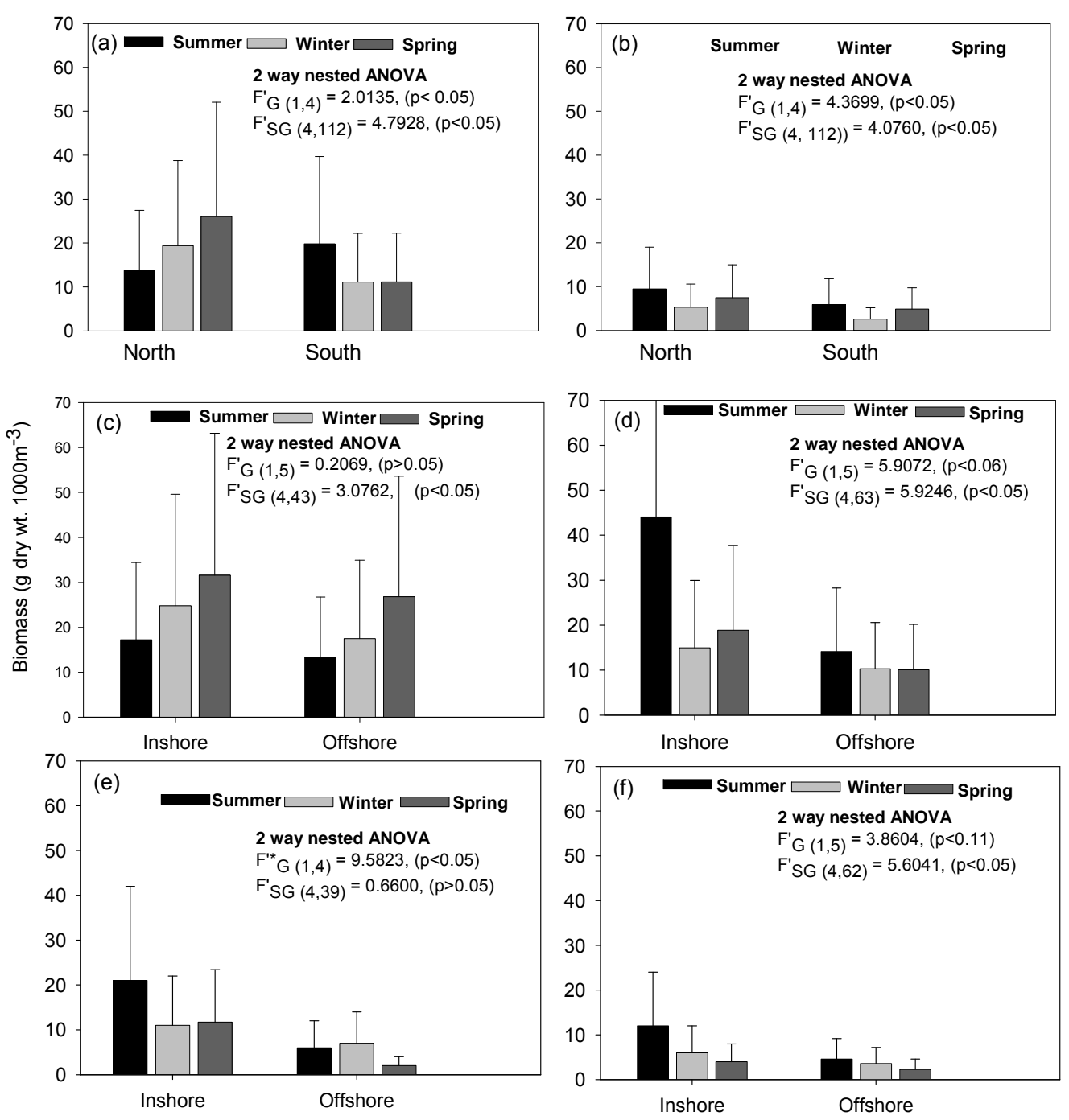

Figure 13 


\begin{tabular}{|c|c|c|c|}
\hline Location & Sampling period & C. Chl a & Source \\
\hline Inshore -North & July - August 1995 / SM & *21 & Bhattathiri et al., 1996 \\
\hline -do- & February - March 1995 / WM & 26 & - do- \\
\hline -do- & May 1994 /SIM & *12 & -do- \\
\hline Inshore -South & July - August 1995 / SM & 52 & - do- \\
\hline -do- & February - March 1995 / WM & *10 & -do- \\
\hline- do- & April - May 1994 /SIM & *11 & - do- \\
\hline Inshore -North & December 1999 - January 2000 / SM & 49 & Jyothibabu et al., 2004 \\
\hline Offshore -North & July - August / SM & 46 & - do \\
\hline Inshore -North & November -December 1999 / WM & 59 & Madhu, 2004 \\
\hline -do- & June 2000 \& 2001 / SM & 21 & - do- \\
\hline Offshore -North & November-December 1999 / WM & 45 & - do- \\
\hline -do- & June $2000 \& 2001$ / SM & 16 & - do- \\
\hline Inshore - south & November-December 1999 / WM & 21 & - do- \\
\hline -do- & June 2000 \& 2001 / SM & 33 & - do- \\
\hline Offshore - south & November-December 1999 / WM & 24 & - do- \\
\hline -do- & June 2000 \& 2001 / SM & 21 & -do- \\
\hline Offshore -North & March 2003 / SIM & *62 & Dwivedi et al., 2006 \\
\hline Offshore - North & March 2004 / SIM & *54 & - do- \\
\hline Inshore - South & September 2003 / SM & 41 & Jyothibabu et al., 2008 \\
\hline Inshore - South & April 2004 / SIM & 13 & - do- \\
\hline Offshore - South & September 2003 / SM & 28 & -do- \\
\hline Offshore - South & April 2004 / SIM & 23 & - do- \\
\hline Inshore - South & April 2004 / SIM & 15 & $\begin{array}{l}\text { Ashadevi et al., } 2009 \\
\quad \text { (unpublished) }\end{array}$ \\
\hline Inshore - South & July - August / SM & 43 & - do- \\
\hline Offshore -South & April 2004 / SIM & 24 & -do- \\
\hline Offshore - South & July - August / SM & 18 & - do- \\
\hline Inshore - South & June 2003 / SM & 60 & $\begin{array}{l}\text { Revichandran, } 2008 \\
\quad \text { (unpublished) }\end{array}$ \\
\hline Inshore - South & December 2003 / WM & 22 & -do- \\
\hline Offshore - North & March 2000/ SIM & 32 & $\begin{array}{l}\text { Madhu et al., } 2008 \\
\quad \text { (unpublished) }\end{array}$ \\
\hline
\end{tabular}

Table 1- Average column chlorophyll $a\left(\mathrm{mg} \mathrm{m}^{-2}\right)$ at different regions of the eastern Arabian Sea recorded in the recent ship measurements. The high values (in bold) corresponds to the seasonal phytoplankton peaks in different geographical regions as discussed in this paper. * indicate sampling at a single location. SM - summer monsoon, WM- winter monsoon and SIM- spring intermonsoon 